\title{
IT'S ABOUT TIME
}

\section{DAVID FRISCH*}

This Article critically evaluates the view widely held by courts that contract claims for lost leisure or personal time do not justify compensation. The thesis of this Article is that while the conventional judicial wisdom may be correct about some forms of nonpecuniary loss, it is entirely wrong regarding lost time. After setting aside assumptions, I show that traditional arguments against this form of recovery are deeply flawed. Most importantly, I rely on the recognition of hedonic damages by forensic economists to debunk the myth that loss of time is no more than an everyday aspect of life not worthy of judicial attention. This Article demonstrates the relevance of lost time claims to remedial policy generally, showing that the denial of these claims undermines the twin remedial policies of fairness and efficient deterrence. Finally, I reject the various hedonic models that have been used to measure leisure time on the ground that they are either administratively cumbersome or are anti-egalitarian, and propose a model that eliminates these two deficiencies.

The lack of judicial and academic attention given to lost personal time claims is somewhat astonishing, considering its prevalence in legal contexts. This trend suggests that the traditional common law position against the recovery of nonpecuniary damages generally has a powerful hold on our judicial intuition. A reevaluation of at least one aspect of this slighted area of law would be good public policy, and it's about time.

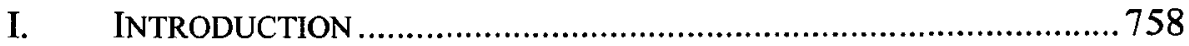

II. IN RE HANNAFORD BROS. CO. CUSTOMER DATA SECURITY BREACH

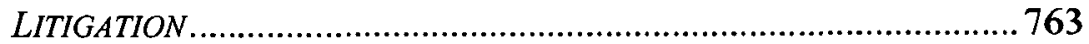

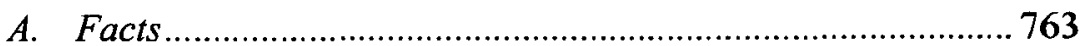

B. The Maine Supreme Judicial Court Opinion .......................... 764

III. A CRITIQUE OF THE MAINE SUPREME JUDICIAL COURT'S OPINION766

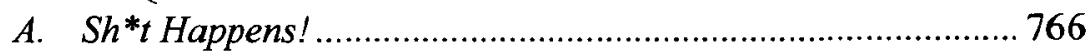

B. Unprincipled Classification ..................................................775

C. The Problem of Measurement ………………........................ 794

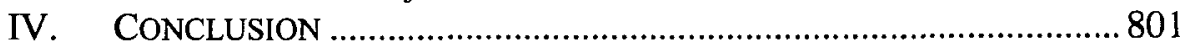

* Professor of Law, University of Richmond School of Law. B.S., University of Pennsylvania; J.D., University of Miami School of Law; LL.M., Yale Law School. I would like to thank John Spurlock-Brown for his research and editorial assistance. 


\section{INTRODUCTION}

While people seldom agree on any proposition without reservation, few would take issue with the old saying that "time is money." Implicit in this saying is the observation that our personal time is the ultimate scarce resource and should not be squandered without receiving something of value (such as money or enjoyment) in return. ${ }^{2}$ In conventional economics, time is treated as a commodity to be bought and sold at will. ${ }^{3}$ However, time is much more than a flow of future income payments. The irreplaceable hours, minutes, and seconds of our lives are used to give and receive love, participate in activities that give us pleasure, and engage in many other life elements that most everyone would agree are important.

There are many ways that people exhibit information about how they value their time. Some of the most obvious examples come in the form of transportation decisions. Travelers regularly pay a considerably higher price for an airline ticket rather than taking a less expensive, but slower, train ride to the same location. Likewise, commuters often choose to drive on a toll road when they can reach the same destination by a free, but less direct route. Employment relationships supply yet another common example. If a worker is normally expected to be at work and receives payment for only eight hours per day, the employer may find it necessary to provide additional compensation, in the form of overtime pay, to obtain more of the worker's time.

We might, therefore, intuitively expect that civil recourse in private law would be readily available against those who wrongfully cause us to lose time by breach of contract or otherwise. Although nonpecuniary damages are a regular feature of compensation claims in contract, ${ }^{4}$ with few

1. The etymology of this phrase is obscure, at best. We know that Benjamin Franklin used it in his ADVICE TO A Young TRADESMAN (1748) ("Remember that time is money. He that idly loses five shillings' worth of time loses five shillings, and might as prudently throw five shillings into the sea."). However, there is a citation slightly earlier than Franklin's that appears in the Oxford English Dictionary, culled from AMBrose PHILLIPS, THE FrEETHINKER 128 (1723) ("In vain did his Wife inculcate to him, That Time is Money: He had too much wit to apprehend her....").

2. We are all time-limited. That is, a person has a limited quantity of time equal to 24 hours in a day. We all crave more time. Suffice it to say that if singer-songwriter Jim Croce had succeeded in saving "Time in a Bottle," the value of that bottle would have been priceless. JIM CROCE, Time in a Bottle, on YOU DON'T MESS AROUND WITH JIM (ABC Records 1972).

3. See, e.g., Kurt V. Krueger, John O. Ward \& Gary R. Albrecht, Introduction to the Whole-Time Concept, 14 J. ForENSIC ECON. 3, 5 (2001) (noting that "money, time, and goods can be equally substituted for each other").

4. Although the primary purpose of this Article is to suggest that lost personal time that results from a breach of contract is a real loss and that the aggrieved party should be compensated for such a loss, nonpecuniary damages recoverable in tort will not be ignored. 
exceptions, these claims have been largely ignored by legal commentators and have received merely cursory treatment by courts. ${ }^{5}$ First, let us understand what is meant by nonpecuniary damages. In my mind, these are damages that compensate for losses that are not generally thought of as being susceptible to measurement in purely economic terms, such as mental suffering, inconvenience, loss of time, or humiliation. ${ }^{6}$

One might argue that there are two general categories of nonpecuniary damage claims that may arise in breach of contract cases. First, there are claims for some type of psychic harm. These are the emotional distress cases, regardless of what other descriptive label a court or litigant may choose to employ. Perhaps the term "psychic harm" might be a classification that better serves as a new and useful grouping of cases in which judges would strive for consistency and litigants would feel empowered to look for precedents. Instead, psychic harm currently does not seem to be a recognized category, and it is simply a feature common to many cases bearing different labels. Second are so-called claims for lost time. The distinguishing feature of these claims is their temporal, not psychic, nature. For some defined period of time, the aggrieved party has

5. See John A. Sebert, Jr., Punitive and Nonpecuniary Damages in Actions Based Upon Contract: Toward Achieving the Objective of Full Compensation, 33 UCLA L. REV. 1565,1578 (1986) ("Nonpecuniary losses, such as inconvenience, annoyance, and emotional distress, although likely real in many situations, are rarely recognized."). The most prominent exception involves the right of the aggrieved party to recover damages for emotional distress. See, e.g., RESTATEMENT (SECOND) OF CONTRACTS $\S 353$ (1981) ("Recovery for emotional disturbance will be excluded unless the breach also caused bodily harm or the contract or the breach is of such a kind that serious emotional disturbance was a particularly likely result."). Typically, emotional distress damages are only awarded in death and burial cases, in cases where the breach is "accompanied by public embarrassment ... of the plaintiff" or in cases where the breach results in physical harm to the plaintiff, as in contracts for medical services. See Sebert, supra, at 1584-85; Douglas J. Whaley, Paying for the Agony: The Recovery of Emotional Distress Damages in Contract Actions, 26 SUFFOLK L. REV. 935, 940 (1992).

6. In continental doctrine, this type of loss is known by the term "dommage moral," that is, damage of a moral nature that does not affect a tangible part of a person's patrimony. Saul Litvinoff, Moral Damages, 38 LA. L. REV. 1, 1 (1977). Such recovery is recognized by statute in Louisiana, a jurisdiction whose law is based in part on civil law.

Damages for nonpecuniary loss may be recovered when the contract, because of its nature, is intended to gratify a nonpecuniary interest and, because of the circumstances surrounding the formation or the nonperformance of the contract, the obligor knew, or should have known, that his failure to perform would cause that kind of loss. Regardless of the nature of the contract, these damages may be recovered also when the obligor intended, through his failure, to aggrieve the feelings of the obligee.

La. Civ. Code AnN. art. 1998 (1985). 
lost the opportunity to engage in an alternative activity; it is in this opportunistic sense that time has been lost. This Article engages lost time from the perspective of claims by individuals who, for one reason or another, are forced to spend their personal or leisure time in undesirable ways, and for which no lost economic opportunity can be readily identified. Claims of this sort can be described as "lost personal time."

It should be apparent that not all lost time claims will necessarily fall into this category. Consider, for example, the question of whether a business buyer can recover for the time spent by its employees on tasks made necessary by the seller's failure to deliver conforming goods. In Keller v. Inland Metals All Weather Conditioning, Inc., ${ }^{7}$ the buyer rightfully rejected a dehumidifier delivered by the seller and sought to recover damages for the time its employees spent gathering temperature and humidity data and transporting water samples for testing. ${ }^{8}$ The trial court allowed this claim and awarded damages based on the employees' respective hourly rates. ${ }^{9}$ On appeal, the Supreme Court of Idaho affirmed, holding that these were incidental damages recoverable under U.C.C. § 2715(1). ${ }^{10}$ Here, the court was not dealing with a claim for nonpecuniary damages; instead, the expense incurred in having employees do something that they were not hired to do could easily be monetized and better classified as a traditional incidental or consequential damages claim.

Some of the contexts, outside of statutory frameworks, ${ }^{11}$ in which claims for lost personal time have been litigated include the "time and effort" expended by those who are affected by data security breaches; ${ }^{12}$ the "inconvenience, aggravation, and distress" due to a service provider's delay in performance; ${ }^{13}$ or a breach of warranty by various types of sellers. ${ }^{14}$

7. 76 P.3d 977 (Idaho 2003).

8. Id. at 979,984 .

9. Id. at 984 .

10. Id. U.C.C. $\S 2-715(1)$ permits a buyer to recover reasonable expenses incurred in the inspection, receipt, transportation, and care and custody of nonconforming goods and any reasonable expense incident to the delay or breach. U.C.C. § 2-715(1) (1977).

11. Inasmuch as my larger goal is to suggest an approach to breach of contract cases, I ignore for the time being areas of the law where legislative enactments dominate the landscape. For a discussion of some of these enactments see infra notes 57-74 and accompanying text.

12. See, e.g., In re Hannaford Bros. Co. Customer Data Sec. Breach Litig., 4 A.3d 492, 496 (Me. 2010) (holding that time and effort expended to avoid or remediate harm caused by fraudulent charges or identity theft by those whose credit card information was stolen was not a cognizable injury for which damages could be recovered under the law of negligence or contract). For more on this case, see infra notes 33-52 and accompanying text.

13. See, e.g., Meador v. Toyota of Jefferson, Inc., 322 So. 2d 802, 805 (La. App. 4th Cir. 1975) (the court denied recovery of damages resulting from defendant's unreasonable delay in repairing plaintiff's automobile because the principal object of the contract was physical gratification or utility). 
There is also the "time lost" as a result of phone calls made to straighten out discovered billing errors by a wireless communications provider. ${ }^{15}$ And then, there is the "inconvenience, loss of time, anxiety and frustration" caused by being bumped as a result of flight overbooking. ${ }^{16}$

These several examples begin to suggest that the challenge of lost personal time claims is an urgent one. That confusion reigns is even evident from the diverse terminology used to describe these claims. What, for example, is the relationship between "lost time" and "inconvenience"? Is "inconvenience" distinct from "distress"? Does it matter? Remarkably enough, no commentator or judge has explained any of these cases with reference to the usual litany of harms alleged. Because these harms share a common currency (i.e., each refers to a reduction in the overall enjoyment of life), discussions of nonpecuniary damages tend to use them interchangeably, creating the appearance of a uniform problem when, in fact, the specific harms may vary widely.

To put this observation in context, consider the court's opinion in Daniel v. Virgin Atlantic Airways Ltd. ${ }^{17}$ The plaintiffs in this case were passengers on a flight from London to San Francisco. ${ }^{18}$ Following an alleged mechanical problem and fuel shortage, the plane was diverted to Vancouver, British Columbia, where it sat "on the tarmac for one hour and fifteen minutes." 19 After the passengers were finally permitted to disembark, they were confined in a transit lounge for one hour and ten minutes. ${ }^{20}$ As a result of the delays, they then had no choice but to spend the night in Vancouver. ${ }^{21}$ This nightmare of a trip finally ended when their plane landed in San Francisco, twenty-five hours after its scheduled arrival. ${ }^{22}$ The plaintiffs claimed damages for "anxiety, exhaustion, frustration, humiliation, inconvenience, mental anguish and physical discomfort.",23 Although the court decided that "emotional distress" is not a legally cognizable harm in the absence of economic or physical injury, it

14. Monsanto Agric. Prods. Co. v. Edenfield, 426 So. 2d 574, 575 (Fla. Dist. Ct. App. 1982); Lobianco v. Prop. Prot., Inc., 437 A.2d 417, 418, 422 (Pa. Super. Ct. 1981).

15. See, e.g., Sisley v. Sprint Commc'ns Co., L.P., 284 Fed. Appx. 463, 466 (9th Cir. 2008) (although the court expressed doubt whether the plaintiff had stated a cognizable injury, it nevertheless reversed the district court's dismissal for want of Article III standing).

16. See, e.g., Lopez v. E. Airlines, Inc., 677 F. Supp. 181, 183 (S.D.N.Y. 1988) (holding that although plaintiff suffered a delay of only three to four hours, he should be compensated for the "inconvenience, delay and uncertainty").

17. 59 F. Supp. $2 d 986$ (N.D. Cal. 1998).

18. Id. at 987.

19. Id.

20. Id.

21. Id.

22. Id.

23. Id. at 992 (internal quotation marks omitted). 
had no qualms about permitting the plaintiffs to recover damages for "inconvenience." ${ }^{24}$ Why? The court's simple answer was that "time is money, after all ....,25

What does this analysis tell us? The answer is that we need to bring greater discipline to the analysis of nonpecuniary damage claims, and, by doing so, reveal trends and tensions in the judicial enterprise that require either a more deliberate or different response. Using, for example, the same term - "inconvenience"- to express both a disruption in the plaintiff's schedule of activities and the distress caused by that disruption is misleading. People who experience emotional turmoil as a result of a breach may, nevertheless, conduct their affairs as planned but with less joie de vivre. Is this inconvenience or something else, such as emotional distress? Whatever we may choose to call it, it is certainly not lost time. Strictly speaking, even time spent by airline passengers on the tarmac, in an airport lounge, or asleep in a hotel room is not time lost. Each passenger is still experiencing life, but not in the manner she would have otherwise chosen. Notwithstanding this quibble with the descriptive accuracy of referring to these claims as "lost time" claims, the term is a useful way of highlighting a shared feature of a set of cases. For this reason, I avoid the temptation to suggest a different description.

With these opening comments in mind, I do not intend to engage the broader debate about whether nonpecuniary damages may be recovered for breach of contract generally. Rather, this Article explores the narrower question of whether damages are appropriate to compensate for lost personal time. ${ }^{26}$ I suggest that they should be recognized. In so doing, I will seek to clear a path for their acceptability by removing certain doctrinal and theoretical impediments to such recognition.

This Article unfolds in two parts. In Part II, I consider in detail the opinion of the Supreme Judicial Court of Maine in In re Hannaford Bros. Co. Customer Data Security Breach Litigation. ${ }^{27}$ This case is a paradigm for the position that damages for lost personal time are non-recoverable, and provides a useful lens through which to analyze the issue. ${ }^{28}$ From my

24. Id. at 994 .

25. Id. Interestingly, the court suggests that the amount of compensation awarded to each plaintiff should reflect what he or she was prevented from doing as a result of the flight delay. Id. at 994 n.6. I argue later in this Article that this brand of discrimination is inappropriate. See infra notes 218-19 and accompanying text.

26. While claims for psychic harm typically accompany claims for lost time, there are significant differences between these two categories of claims that require separate treatment. For one thing, there is no metric for measuring the value of the former; whereas, this Article will suggest that there is a metric for the latter. See infra notes 211-21 and accompanying text.

27. 4 A.3d 492 (Me. 2010).

28. See id. at 496 ("An individual's time, alone, is not legally protected from the 
perspective, the court's conclusion and reasoning unfortunately are completely wrong. Understanding why this is so requires a much closer look at the objections to recovery on which the court's opinion is based; that will be the key task of Part III. I then conclude with a proposal for determining the appropriate amount of an award for loss of personal time.

\section{IN RE HANNAFORD BROS. CO. CUSTOMER DATA SECURITY BREACH LITIGATION}

\section{A. Facts}

The events between December 2007 and March 2008 that gave rise to the litigation in Hannaford involved a breach of the computer systems of the Maine-based grocery store chain. ${ }^{29}$ This led to a consolidated class action brought by customers whose credit and debit card data became compromised by the breach. ${ }^{30}$ A significant legal obstacle that faced the Hannaford plaintiffs was that, at the end of the day, few class members actually sustained financial harm. ${ }^{31}$ Importantly, even in those instances where the thieves used the stolen debit or credit card information to make fraudulent charges, there was little or no out-of-pocket loss to the victims. ${ }^{32}$ Consequently, the plaintiffs had to aver that they were harmed in some other concrete way. ${ }^{33}$ And this they did. The plaintiffs claimed that they were entitled to be reimbursed for their expended "time, energy and expense" to ameliorate the financial disruption caused by the security breach. $^{34}$ Among other things, they had to take the necessary steps to identify and contest the fraudulent charges, cancel their existing cards, and deal with pre-authorized charges by registering new cards with online sellers and other payees to whom pre-authorized payments were made. ${ }^{35}$

negligence of others.").

29. Id. at 494 .

30. Id.

31. Id.

32. See id. The Truth in Lending Act limits the liability of a consumer for unauthorized charges to \$50. Truth in Lending Act of $1968 \S 133,15$ U.S.C. $\S 1643(a)(1)$ (2006). Even the $\$ 50$ charge is often waived by the issuer. See, e.g., Visa Security \& Protection, Zero Liability, VISAUSA, http://usa.visa.com/personal/security/visa_security_pr ogram/zero_liability.html (last visited Jan. 15,2012 ). The same $\$ 50$ liability limitation is also applicable to the unauthorized use of a debit card, provided the consumer reports the loss of the card within a prescribed amount of time. See Electronic Fund Transfer Act of $1978 \S 909,15$ U.S.C. $\S 1693 \mathrm{~g}(2006)$.

33. In re Hannaford Bros. Co. Customer Data Sec. Breach Litig., 613 F. Supp. $2 \mathrm{~d} 108$, 115 (D. Me. 2009).

34. Id. at 116 .

35. Id. 
Accordingly, In re Hannaford can be viewed as a lost personal time case, pure and simple.

The defendants sought a dismissal of the claims of the named plaintiffs whose data had been stolen but who had not suffered any out-of-pocket losses as a result of the theft. ${ }^{36}$ Maine District Court Judge D. Brock Hornby initially granted the defendants' motion as to all but one of the plaintiffs' claims, holding that consumers could not be compensated for "the ordinary frustrations and inconveniences that everyone confronts in daily life with or without fraud or negligence" because there was no way to monetize such a claim. ${ }^{37}$

The plaintiffs then asked Judge Hornby to reconsider his ruling, arguing that it was by no means clear how Maine's highest court, if given the opportunity, would decide the question of whether lost time is a legally cognizable injury. ${ }^{38}$ Judge Hornby agreed with the plaintiffs, and proceeded to certify two questions of state law to the Maine Supreme Judicial Court. ${ }^{39}$ The state's high court only addressed the following question:

In the absence of physical harm or economic loss or identity theft, do time and effort alone, spent in a reasonable effort to avoid or remediate reasonably foreseeable harm, constitute a cognizable injury for which damages may be recovered under Maine law of negligence and/or implied contract? ${ }^{40}$

The court's answer was an emphatic "No."

\section{B. The Maine Supreme Judicial Court Opinion}

The state supreme judicial court's brief opinion is best understood in the context of examining whether damages for lost personal time can be recovered through the lens of what the court saw as a series of useful categories. The court first considered the category of tort and the sub-

36. Id. at 115 .

37. Id. at $134-35$.

38. In re Hannaford Bros. Co. Customer Data Sec. Breach Litig., 660 F. Supp. 2d 94, 97-98 (D. Me. 2009).

39. In re Hannaford Bros. Co. Customer Data Sec. Breach Litig., 4 A.3d 492, 494 (Me. 2010). See also In re Hannaford Bros. Co. Customer Data Sec. Breach Litig., 617 F. Supp. 2d 198, 201 (D. Me. 2009) (certifying questions to the Supreme Judicial Court of Maine).

40. In re Hannaford, 4 A.3d at 494. The Supreme Judicial Court did not address the second question, which was, "If the answer to question \# 1 is yes under a negligence claim and no under an implied contract claim, can a plaintiff suing for negligence recover damages under Maine law for purely economic harm absent personal injury, physical harm to property, or misrepresentation?"

41. Id. at 498 . 
category of negligence ${ }^{42}$ It was quick to point out that negligence provides no recourse "for the typical annoyances or inconveniences that are part of everyday life," and that damage claims for personal time are within this category of non-compensable harms. ${ }^{43}$ Yet the court failed adequately to articulate a coherent explanation for why this is so. It did suggest, however, that recovery was denied because the loss in question could not be assigned a value. ${ }^{44}$ Thus, we are told that damages for lost time can be recovered if the plaintiff alleges personal injury or property damage and if the loss can be correlated to either earnings or earning opportunities (i.e., pecuniary damages).$^{45}$ The court then continued with its categorization of tort claims. In its view, the cases relied on by the plaintiffs that allowed recovery for loss of time were distinguishable because many of them involved at least one intentional tort. ${ }^{46}$ The court thus reasoned that "because liability is often more extensive in cases of intentional torts than those in negligence, intentional tort cases recognizing recovery for time and effort have little bearing on our analysis. ${ }^{, 47}$ As well, it rejected the persuasive value of those cases cited because they offered no guidance as to how the value of lost time should be measured. ${ }^{48}$

Finally, the court turned its attention to the plaintiffs' breach of contract claim. The analysis began with the recognition that "contract damages are more restricted than compensatory damages for a tort ${ }^{, 49}$ and ended with the court reiterating Judge Hornby's existential observation about the frustrations and inconveniences of everyday life. ${ }^{50}$ Thus, those plaintiffs who have suffered no direct financial loss are without a right of action regardless of whether their claim is said to arise out of contract or tort. ${ }^{51}$

42. $4 \mathrm{~A} .3 \mathrm{~d}$ at 496 .

43. Id.

44. See id. ("Because the time in question could be assigned a value ... resulting from personal injury or property damage, loss of time was a harm cognizable in negligence.").

45. Id.

46. Id. at 497 n.1; see, e.g., Prentiss v. Shaw, 56 Me. 427, 431, 435 (1869) (false imprisonment); Brown v. Watson, 47 Me. 161, 163 (1859) (nuisance).

47. 4 A. $3 d$ at 497.

48. Id.

49. Id. The court makes this point by stressing that damages for emotional distress are typically unavailable in a breach of contract action. Id.

50. Id.

51. See id. at 498. This is a conclusion of real import. If case law is any indication, the theft or loss of personal information after it has been shared with another is a growing problem. In some cases, the information is obtained by hackers, see, e.g., Bell v. Acxiom Corp., 2006 U.S. Dist. LEXIS 72477, at *2 (E.D. Ark. Oct. 3, 2006); Belle Chasse Auto. Care, Inc. v. Advanced Auto Parts, Inc., No. 08-1568, 2009 U.S. Dist. LEXIS 25084, at *2 (E.D. La. March 24, 2009). Sometimes the computer itself is stolen, see, e.g., Randolph v. ING Life Ins. \& Annuity Co., 486 F. Supp.2d 1 (D.D.C. 2007); Caudle v. Towers, Perrin, Forster \& Crosby, Inc., 580 F. Supp. 2d 273, 275 (S.D.N.Y. 2008); Kahle v. Litton Loan 


\section{A CRITIQUE OF THE MAINE SUPREME JUDICIAL COURT'S OPINION}

The brief discussion of relevant legal doctrine in Hannaford is stronger on rhetoric than analysis. This is a shame, because the fact pattern in the case presents a wonderful opportunity for exploring the doctrinal issues posed by a claim for damages for lost personal time, a subject that is far more complex and interesting than the court's opinion implies. Let us put some flesh on the bare bones of the opinion, and, in so doing, take a closer look at the justifications for the limitations on liability that the court found to be persuasive.

\section{A. Sh*t Happens!}

The first aspect of the Hannaford opinion that deserves a closer look is the court's supposition that the time and effort expended by the plaintiffs was no more than the "typical annoyances and inconveniences that are a part of everyday life." $52 \mathrm{Or}$, to put it in more colloquial terms, "sh*t happens." Perhaps the court only meant to say that it has never shaped its negligence and contract doctrines with the object of recognizing a standalone claim for lost time. But it would not necessarily be a mistake to read the statement more broadly, and to suggest that there are two entirely separate categories of harms: those of the "grin and bear it" variety for which no legal recourse is available and those for which there is. However, this observation gives no indication as to why the loss of time alone should fall within the former category and not the latter. As part of everyday life, we also encounter negligent automobile drivers who cause personal injury or property damage and those who breach contracts, causing the aggrieved party to lose value directly as a result of the breach. ${ }^{53}$ Yet, no court would tell the person lying in a hospital bed because of someone else's negligence or the pizza restaurant owner who is forced out of business because his

Serv'g LP, 486 F. Supp. 2d 705, 706 (S.D. Ohio 2007). Of the latter variety is Krottner v. Starbucks Corp., 406 Fed. Appx. 129 (9th Cir. 2010). Notwithstanding the plaintiffs' claim that they were required to spend an inordinate amount of time monitoring their banking and financial accounts, the Ninth Circuit dismissed the state law claims for negligence and breach of contract based on Washington law. Ignoring the lost time component of the claim, the court held that "mere danger of future harm" is not a cognizable injury. Id. at 131.

52. In re Hannaford Bros. Co. Customer Data Sec. Breach Litig., 4 A.3d 492, 496 (Me. 2010). The district court reached the identical conclusion and expressed it in almost identical language. In re Hannaford Bros. Co. Customer Data Sec. Breach Litig., $613 \mathrm{~F}$. Supp. 2d 108, 134 (D. Me. 2009) (stating that the plaintiffs' time and effort represented 'the ordinary frustrations and inconveniences that everyone confronts in daily life").

53. This is usually measured by the difference in value between what was promised and what was received, see U.C.C. § 2-714(2) (2012), or the additional expense of obtaining a replacement, see U.C.C. § 2-712 (2012), or its value. U.C.C. § 2-713 (2012). 
pizza oven is delivered late that they have no recourse because "hey, that's everyday life."

The Hannaford opinion lacks a convincing account of the criteria by which claims for lost time should be compared to, and therefore distinguished from, the vast array of compensable harms. After all, if our goal is compensation, ${ }^{54}$ then the fact of wrongdoing rather than the form that the resulting harm takes ought to be sufficient to empower plaintiffs to prevail on the merits of their claims. However, this proposition assumes the absence of practical or theoretical stumbling blocks to the recognition of a particular form of harm. For example, many courts have denied recovery for emotional distress because of the risk of fabricated or exaggerated claims $^{55}$ or because there is no market standard to measure its value. ${ }^{56} \mathrm{As}$ will be shown, these are not concerns that should caution against allowing recovery for lost personal time.

Perhaps implicit in the Hannaford court's characterization of the lost time claim as one of life's ordinary frustrations is the belief that plaintiffs were not really harmed at all. If they were not harmed, they therefore needed no protection from actions that were not harmful. Beyond the cliched "time is money" response to this position, there is both judicial and legislative evidence to the contrary. As previously indicated and as discussed infra, there is not a blanket prohibition against damages for lost personal time in all cases. Thus, the court that refuses to value lost personal time in one context would have to explain why it suddenly takes on value in a different context.

In recent years, we have also witnessed a growing legislative awareness that personal time has value. In September 2008, President George W. Bush signed the Identity Theft Enforcement and Restitution Act of 2008 ("the Act"). ${ }^{57}$ The Act applies to both online and offline information theft, amending 18 U.S.C. $\S 3663$ (b) to require identity thieves convicted under the Act to "pay an amount equal to the value of the time reasonably spent by the victim in an attempt to remediate the intended or actual harm incurred by the victim from the offense." $"$ Unfortunately, the Act is of little help in a Hannaford-type case. The information thief has typically vanished or is insolvent, so the victims' sole recourse is against the company to whom they entrusted their information. With regard to such a claim, the Act is silent.

54. See infra notes $\mathbf{1 7 2 - 7 6}$ and accompanying text. 1993)

55. See, e.g., Garvis v. Employers Mut. Cas. Co., 497 N.W.2d 254, 257 n.3 (Minn. 1984).

56. See, e.g., Valentine v. Gen. Am. Credit, Inc., 362 N.W.2d 628, 630, 631 (Mich.

57. Pub. L. No. 110-326, 122 Stat. 3560.

58. 18 U.S.C. $\S 3663(b)(6)(2011)$. 
Moreover, in considering the question of whether compensation for lost personal time can be recovered for violation of statutes that do not expressly speak to the matter, federal courts have shown a marked willingness to answer in the affirmative. For example, in Hurry v. Jones, ${ }^{59}$ the First Circuit Court of Appeals was presented with this issue in the context of a claim under the Education for All Handicapped Children Act of 1975 (EAHCA) ${ }^{60}$ EAHCA provided "that a state receiving federal assistance for education of the handicapped must assure a free appropriate public education.",61 As well, EAHCA provided "that parties aggrieved by decisions affecting a handicapped child's education may bring a civil action in state or federal court" for "such relief as the court determines is appropriate." ${ }^{\prime \prime 62}$ The parents of George Hurley, a physically and mentally handicapped minor, sought damages from school and transportation officials for the officials' failure to provide George with door-to-door transportation to and from school. ${ }^{63}$ Among other items of damages, the district court awarded the Hurleys $\$ 4,600.00$ for the time they were forced to spend driving George, an amount the court calculated on the basis of $\$ 10.00$ per day for the daily round trips. ${ }^{64}$ The First Circuit affirmed the award. ${ }^{65}$ The court held that recovery under EAHCA was not limited to outof-pocket expenses, but could also include compensation for the expenditure of time and effort. ${ }^{66}$ Although the court recognized the risk of overcompensation when reimbursing plaintiffs for the monetary equivalent of time and effort, it thought the risk non-existent in this case because the award was "obviously a bare-bones figure, well within any reasonable estimate of fair reimbursement." $" 67$

Another statutory case in which the lost time damages issue was squarely presented to the court is Beaven v. United States Dept. of Justice. ${ }^{68}$ In Beaven, prison employees alleged that the defendants allowed an

59. 734 F.2d 879 (1st Cir. 1984).

60. Pub. L. No. 94-142, 89 Stat. 773. This is the predecessor statute of what is now the Individuals with Disabilities Education Act, 20 U.S.C. $\S \S 1400-82$ (2011).

61. Hurry, 734 F.2d at 882 .

62. Id.

63. Id. at 881 .

64. Id. at 884 .

65. Id. at 885 .

66. Id. at 884 .

67. Id. Similarly, in a case brought under what is now the Individuals with Disabilities Education Act, the Third Circuit affirmed an award of $\$ 6,842.00$ to the parent of a disabled child for the time she had to spend in providing therapy to her daughter after the county failed to provide that service. Bucks Cnty. Dep't of Mental Health/Mental Retardation v. Pennsylvania, 379 F.3d 61 (3d Cir. 2004). The amount of reimbursement was based on a rate of $\$ 22$ per hour, approximately half of what it would have cost the county to provide the same treatment. Id. at 69-70.

68. 622 F.3d 540 (6th Cir. 2010). 
employee roster containing their sensitive personal information to be disclosed to prison inmates and other prison staff. ${ }^{69}$ The plaintiffs sought to recover lost time damages under the Privacy Act of 1974 (the "Act"). ${ }^{p 0}$ The purpose of the Act is to address the handling of personal information by the federal government and to provide a remedy when that information is mishandled. $^{71}$ One cannot, therefore, overstate the importance of the damages provision, which reads as follows:

In any suit brought under the provisions of subsection $\mathrm{g}(\mathrm{l})(\mathrm{C})$ or (D) of this section in which the court determines that the agency acted in a manner which was intentional or willful, the United States shall be liable to the individual in an amount equal to the sum of $-(A)$ actual damages sustained by the individual as a result of the refusal or failure, but in no case shall a person entitled to recovery receive less than the sum of $\$ 1,000$; and (B) the costs of the action together with reasonable attorney fees as determined by the court. ${ }^{72}$

The language of this provision immediately raises at least one question: What did Congress mean by the term "actual damages"? Was the definition intended to be a narrow one that excludes recovery for nonpecuniary harms, or is a more expansive understanding of the term appropriate? This question has been litigated repeatedly and the circuits are split. ${ }^{73}$ By contrast, because persons whose personal information is compromised may suffer in a myriad of ways that cannot be easily measured in terms of dollars and cents, commentators are unanimous in their position that the efficacy of the Act depends upon its application to nonpecuniary harms. If not, they argue, the Act would be rendered "[t]oothless."

69. Id. at 544 .

70. Id. See generally Privacy Act of 1974, Pub. L. No. 93-579, 88 Stat. 1896 (current version codified at 5 U.S.C. $\$ 552 \mathrm{a}(2011))$.

71. See Privacy Act $\S \S 2(b)(1)-(6), 88$ Stat. 896.

72. 5 U.S.C. $\$ 552 \mathrm{a}(\mathrm{g})(4)(2011)$.

73. Compare Fanin v. U.S. Dep't of Veterans Affairs, 572 F.3d 868, 872 (11 th Cir. 2009) (deciding that "[o]btaining monetary damages under $\S 552 \mathrm{a}(\mathrm{g})(4)$ requires proof of 'actual damages,' and in this circuit, that means pecuniary losses"), and Hudson v. Reno, 130 F.3d 1193, 1207 (6th Cir. 1997) (deciding that "actual damages under the Privacy Act do not include recovery for 'mental injuries, loss of reputation, embarrassment or other nonquantifiable injuries"'), and Fitzpatrick v. IRS, 665 F.2d 327, 328 (11 th Cir. 1982) (deciding that "damages under the Privacy Act are recoverable only for proven out-of-pocket losses"), with Johnson v. Dep't of Treasury, 700 F.2d 971, 972 (5th Cir. 1983) (deciding that damages for mental injuries can be recovered as "actual damages").

74. See Anne S. Kimbol, The Privacy Act May be Toothless, Health LaW PerSPECTIVES, (Sept. 2008), http://law.uh.edu/healthlaw/perspectives/homepage.asp.; Alex Kardon, Damages Under the Privacy Act: Sovereign Immunity and a Call for Legislative Reform, 34 HaRv. J.L. \& PUB. POL'y 705, 767 (2011) (“An interpretation of the term 'actual 
Returning to Beaven, the Sixth Circuit was able to dodge the plaintiffs' request to reconsider its prior decision in Hudson $v$. Reno ${ }^{\text {is }}$ by drawing a sharp distinction between damages for lost time and those that would compensate for some sort of mental harm. As the court put it:

Plaintiffs" "lost time" damages does not require us to decide whether actual damages may include non-pecuniary losses-any Privacy Act injury incurred in the form of lost time is necessarily a pecuniary harm that is readily determined and does not require the court to speculate in the same manner as general or presumed damages. ${ }^{76}$

The court then remanded the case to give plaintiffs the opportunity to prove their out-of-pocket losses to support their claim for lost time damages. ${ }^{77}$

The logical problem with labeling lost time as a pecuniary loss is that it seems to depend crucially on the claim that a metric exists by which to measure the loss. This is obviously the case in situations where the plaintiff can show that because of the defendant's wrongful act she was deprived of the opportunity to engage in an income generating activity. The Beaven court made reference in its opinion to the plaintiffs' brief, in which they chose their hourly wage rate as the appropriate factor by which to measure their damages. ${ }^{78}$ The court chose not to explore the reason for this choice. If it was because the plaintiffs had to take time off from work for which they were not paid, then using their hourly wage in making the damages calculation makes perfect sense; this is analogous to calculating lost profits which can be recovered if proved with reasonable certainty. ${ }^{79}$ On the other hand, if the plaintiffs are suggesting that their hourly wage should be used

damages' that excludes recovery for nonpecuniary harms . . . would in fact render the Privacy Act toothless."). See also Daniel Solove, The Nature of Privacy Harms: Financial and Physical Harm vs. Emotional and Mental Harm, CoNCURRING OPINIONS (Jan. 15, 2010 8:01 AM), http://www.concurringopinions.com/archives/2010/01/the-nature-of-privacyharms-financial-and-physical-harm-vs-emotional-and-mental-harm.html (opining that excluding recovery for nonpecuniary harms would "mak[e] a total mockery of the Privacy Act").

75. 130 F.3d 1193, 1207 (6th Cir. 1997). Recall that the Hudson court determined "actual damages under the Privacy Act do not include recovery for mental injury, loss of reputation, embarrassment, or other non-quantifiable injuries." Id.

76. Beaven v. U.S. Dep't of Justice, 622 F.3d 558 n.13 (6th Cir. 2010).

77. Id. at $559-60$.

78. Id. at 558 .

79. See Dan B. DobBs, Handbook on the LaW of Remedies 153-58 (West 1973). This approach to valuation is also consistent with a distinction long recognized by courts and is based on a division of time into work and leisure activities. Loss of the capacity to work is considered an economic loss, whereas loss of the ability to enjoy leisure time is intangible and not appraised as economic loss. 
to value the hours of leisure time that they were forced to sacrifice in order to deal with the disclosure of their personal information, then their choice seems to have been the result of intuition rather than reasoned analysis. An explanation may be that the more litigants are left to their own devices in their attempts to convert nonpecuniary losses into pecuniary losses capable of being included in the elements of economic damages, the more they tend to use simple linear calculation strategies such as multiplying the number of hours lost by the amount of hourly earnings. Although this metric is commonly associated with the valuation of leisure time, I ultimately reject its use later in this Article in favor of an approach that would facilitate a simpler and more consistent law of damages. ${ }^{80}$ The only point emphasized here is that when courts no longer feel shackled by common law restraints, they have shown a willingness to recognize lost time as real harm that is worthy of compensation.

Recent years have also seen pressures on courts to allow so-called hedonic damages in wrongful death actions. ${ }^{81}$ The idea is that the value of a person's life is more than the full economic loss measured by the present value of the decedent's market earnings and non-market services; there are also non-market losses that relate to the leisure activities and emotions that make life worth living. One economist has explained the concept of hedonic damages as follows:

It derives from the word pleasing or pleasure. I believe it is a Greek word. It is distinct from the word economic. So it refers to the larger value of life, the life at the pleasure of society, if you will, the life - the value including economic, including moral, including philosophical, including all the value with which you might hold life, is the meaning of the expression "hedonic value." 82

Presumably, a policy of compensating tort victims for losses or of deterring torts would not be fostered to the same degree as it would be if compensation were not allowed for unconventional-albeit real-forms of loss. ${ }^{83}$ If there are policy reasons to require wrongdoers to pay for hedonic losses (the diminishment of the enjoyment of a person's life) when a life ends, those same policy considerations would support damages for lost personal time in non-death contexts. After all, if we accept the notion that

80. See infra notes 217-21 and accompanying text.

81. See generally Andrew Jay McClurg, It's a Wonderful Life: The Case for Hedonic Damages in Wrongful Death Cases, 66 NOTRE DAME L. REV. 57 (1990).

82. Sherrod v. Berry, 629 F. Supp. 159, 163 (N.D. 11l. 1985) (testimony of expert witness).

83. See, e.g., W. Kip Viscusi, The Value of Life: Has Voodoo Economics Come to the Courts?, 1990 J. FORENSIC ECON. 1, 3 (arguing that loss of enjoyment of life damages has what he calls "deterrence values"); see also infra notes 172-74 and accompanying text. 
being unable to enjoy the totality of the minutes, hours and days that make up a person's life is worthy of compensation, it would follow that if an individual is prevented from enjoying leisure activities for some period of time that is merely a component part of her life, that loss too should be worthy of compensation.

Given that economic analysis supports the award of hedonic damages, one may ask why they have not become commonplace in death cases. The conceptual framework of survival statutes and of most wrongful death statutes is relevant in answering this question. The problem that arises in connection with hedonic damages in these actions is not that the loss of non-market time (enjoyment of life) has no recognized value; it is that the typical statute makes recovery an uphill battle. ${ }^{84}$

Survival statutes allow an individual's estate to recover damages that a decedent, if still alive, could maintain a legal action to recover. ${ }^{85}$ The obvious difficulty is the fact that if, hypothetically, the decedent were still alive, there would be no loss of life damages. ${ }^{86}$ Accordingly, the legal action is treated as if it was a personal injury action from the injury to the individual's death, but then becomes a wrongful death action thereafter. The difficulty is that in a typical wrongful death action, it is the loss to the

84. See McClurg, supra note 81 , at 90-91. Many of the problems that have plagued plaintiffs seeking hedonic damages can be traced to the inherent difficulty of placing a dollar value on the loss. Id. at 68-71 (discussing the speculative nature of hedonic damages). See infra notes 211-18 and accompanying text (discussing some of the methods that have been devised to measure hedonic damages).

85. See McClurg, supra note 81 , at 91 .

86. Andrew McClurg summed it up this way:

Hedonic damage claims do not fit within this statutory scheme because they are predicated upon the death itself: the decedent's estate seeks damages for the harm inflicted by death - the loss of life. Survival statutes merely authorize the damages to which the decedent would have been entitled had he lived. Had he lived, however, the decedent would have had no claim for lost life. Accordingly, lost-life damages are unavailable under true survival statutes.

McClurg, supra note 81 at 91 . Most jurisdictions do permit the recovery of lost enjoymentof-life damages in non-death cases. Samuel R. Bagenstos \& Margo Schlanger, Hedonic Damages, Hedonic Adaptation, and Disability, VAND. L. REV. 745, 748 (2007). The issue there is whether these damages should be separately measured or are more properly considered to be a component of a general award for pain and suffering. Compare, for example, Poyzer v. McGraw, 360 N.W.2d 748, 753 (Iowa 1985) (an award for pain and suffering necessarily includes damages for lost enjoyment of life), and Blodgett v. Olympic Sav. \& Loan Ass'n, 646 P.2d 139, 145-46 (Wash. Ct. App. 1982) (same), with Thompson v. Nat'l R.R. Passenger Corp., 621 F.2d 814, 824 (6th Cir. 1980) (damages for pain and suffering and damages for lost enjoyment of life are not duplicative), and Mariner $v$. Marsden, 610 P.2d 6, 12 (Wyo. 1980) (same). 
survivors that counts, not the loss to the decedent ${ }^{87}$ The value of lost time to the decedent thus becomes relevant only to the extent that it leads to losses by the relevant survivors. ${ }^{88}$

Although the foregoing statutory obstacles have deterred courts from permitting hedonic damages in state law death cases, when other statutes are called into play, judicial reception to these damages has been quite different. ${ }^{89}$ For example, federal courts have been sensitive to the benefits attending hedonic damages in civil rights actions brought under 42 U.S.C. $\S$ $1983 .{ }^{90}$ The challenge these courts face, however, is to discover a basis for ignoring state law restrictions on loss of life damages in wrongful death cases. ${ }^{91}$ The key analytical step to accomplishing this is to establish that a state law restriction on such recovery is "inconsistent with the Constitution and laws of the United States." ${ }^{, 92}$ Although the U.S. Supreme Court has not addressed this issue, it has received the attention of several lower federal courts. ${ }^{93}$ For example, when faced with a Wisconsin statutory scheme that did not allow damages for loss of life, the Seventh Circuit succinctly declared:

87. See McClurg, supra note 81 at 93.

88. See, e.g., McClurg, supra note 81 at 93 . The author explains:

The wrongful death action is for the benefit of the statutorily designated survivors. The object is to compensate survivors for the losses they suffer because of the death of a loved one. The damages that are available - lost pecuniary contributions of the decedent supplemented in most states by damages for loss of society and/or mental anguish - correspond with this purpose.

89. Id. In fact, Congress on occasion has seen fit to expressly authorize the award of hedonic damages within the statute itself. Such is the case for example with the law creating the September 11 fund. See September 11th Victim Compensation Fund of 2001, 49 U.S.C. $\S 40101$.

90. See, e.g., McClurg, supra note 81 , at 80 (observing that "[b]y far, the warmest reception for lost life damages has been in federal courts entertaining actions under 42 U.S.C. § 1983").

91. 42 U.S.C. $\S 1988$ "directs courts to apply state law where the federal civil rights statutes are deficient in the provisions necessary to furnish suitable remedies." Id at 81 . There is little doubt that section 1983 is deficient as to damages issues. $I d$. at 81 ("Section 1983 , consisting of only a single operative sentence, is deficient as to many issues of substantive law, including damages issues.").

92. Id.; 42 U.S.C. $\$ 1988(2006)$.

93. The United States Supreme Court has, however, held that loss of enjoyment of life damages can be recovered in personal injury cases brought under the Federal Tort Claims Act. In Molzoff v. United States, 502 U.S. 301 (1992), the Supreme Court disagreed with the definition of prohibited punitive damages under the FTCA as any damages that go beyond compensating for actual pecuniary loss. This ruling is a clear indication of the Court's willingness to expand victim's rights to include nonpecuniary damages. 
In sum, we hold that Wis. Stat. $\S \S 895.01$ and 895.04 , along with Wisconsin decisions construing those provisions, which would preclude recovery to [decedent's] estate for loss of life, are inconsistent with the deterrent policy of Section 1983 and the Fourteenth Amendment's protection of life. The Wisconsin law therefore cannot be applied to preclude the $\$ 100,000$ damages recovered by [decedent's] estate for loss of life. $^{94}$

In light of this statement, the court's approach might be understood as clear recognition of legislative intent on the question of deterrence. Of course the notion of deterrence should not be taken as a mechanical application of some actual legislative decision; Congress has rendered no general decision about what remedies are needed to effectuate the policies behind $\S 1983 .^{95}$ In the absence of a clear statement, however, allowing the estate of victims killed in violation of their constitutional rights to recover for loss of life would be consistent with Congress's concern for protecting life and might improve the operation of the civil rights statute.

Thus far I have focused on legislative and corresponding judicial developments that give recognition to the normative view that the forced inability to pursue leisure or recreation (i.e., the inability to use one's time as one wishes) should be treated as a separate category of noneconomic damages that can be recovered by an aggrieved party. This poses a forceful challenge to the Hannaford court's conception of the plaintiffs' lost time in this context as "typical annoyances or inconveniences that are part of everyday life." courts not only fail to recognize this crucial aspect of damages, but cannot provide a critical framework for distinguishing recoverable from nonrecoverable noneconomic damages in particular contexts. Yet, because recoveries for noneconomic damages for lost leisure time are needed to fully compensate aggrieved parties and deter wrongful conduct, their preclusion also undermines the claim that economic theory has much to say about the rationality of damage awards. ${ }^{97}$

94. Bell v. City of Milwaukee, 746 F.2d 1205, 1240 (7th Cir. 1984). See also Linzie v. City of Columbia, 651 F. Supp. 740, 742 (W.D. Mo. 1986) (holding that recovery for loss of life is consistent with Section 1983's deterrent policy); Guyton v. Phillips, 532 F. Supp. 1154 (N.D. Cal. 1981) (holding that recovery for loss of life is permitted, but future earnings of decedent should not be factored into recovery for loss of life).

95. See Bell, 746 F.2d at $1239-40$ (observing that "the fundamental policies behind Section 1983 are twofold: compensation for and deterrence of unconstitutional acts committed under state law").

96. In re Hannaford Bros. Co. Customer Security Breach Litig., 613 F. Supp. 108, 134 (N.D. Me. 2009).

97. See infra notes $189-95$ and accompanying text. 


\section{B. Unprincipled Classification}

As previously discussed, the Hannaford court uses a classification discourse that treats damages differently, depending on whether the underlying substantive claim involves an intentional tort, the negligent damage or destruction of personal property or personal injury, or a breach of contract. ${ }^{98}$ Given this mode of analysis, it is now relevant to inquire whether a cause of action approach to the damage rules applicable to the loss of personal time is conceptually valid. Notwithstanding the lack of explanation by the court, the Hannaford court's opinion is arguably consistent with traditional doctrine and the dictates of precedent. ${ }^{99}$ As I explain below, however, equity and social utility suggest that there are no persuasive grounds for treating the different categories of claims differently.

As a starting point, it is worth noting that to suggest that doctrinal categories are sensible tools for rationalizing outcomes may not attract much argument. ${ }^{100}$ Such an approach to decision-making is in many cases reasonable, or even efficient. Presumably, those who are called upon to interpret and apply the law (namely, judges) are more likely to reach predictable results when they need only situate their decisions within an existing categorical framework. ${ }^{101}$ As Roscoe Pound explained:

Classification is a shaping and developing of traditional systematic conceptions and traditional systematic categories in order to organize the body of legal precepts so that they may be: (1) Stated effectively with a minimum of repetition, overlapping, and potential conflict, (2) administered effectively, (3) taught effectively, and (4) developed effectively for new situations.

However, the costs of a system in which case outcomes are predetermined by whichever category the court feels is applicable may sometimes cause us to think twice about the utility of our basic structures of doctrinal classification. As is sometimes the case, the relevant category may

98. See supra notes $27-51$ and accompanying text.

99. See supra notes $45-47$ and accompanying text.

100. See, e.g., Jay M. Feinman, The Jurisprudence of Classification, 41 STAN. L. REV. 661, 664 (1989) (noting that "[c]lassification in law is an important and ubiquitous aspect of legal reasoning"); Cass R. Sunstein, Burkean Minimalism, 105 MiCH. L. REV. 353, 356 (2006) (noting that "[judicial] interpretation should be conservative in the literal sense respecting settled judicial doctrine but also deferring to traditions").

101. See Feinman, supra note 100 , at 676 ("Consistency in particular entails the internal consistency of treating like cases alike and different cases differently, and the external consistency of justifying results according to some general, positive, public principle. Classification helps maintain the order and validity of the legal process.").

102. Roscoe Pound, Classification of Law, 37 HARV. L. REV. 933, 944 (1924). 
be unclear or a particular fact pattern may not quite fit within an existing category. ${ }^{103}$ As a result, there may be increased instances where judges are less than forthright when presenting the legal justification for their opinions. ${ }^{104}$ Moreover, a legal system built around categories with separate and distinct rules may lead to a certain amount of rigidity, which makes the system less flexible and able to adapt to a changing society. ${ }^{105}$ Finally, a serious problem of consistency may result from the overlap between two or more substantive doctrines.

Although the foregoing classification issues are general and can arise in all fields of law, they have been of particular concern to contract and tort scholars. Several insights can be drawn from the much-litigated "economic loss rule." This rule has potential application to two broad categories of cases: (1) cases where the plaintiff has a contractual relationship with the seller of a defective product, and (2) cases where the plaintiff brings a negligence action against a contractual stranger. ${ }^{106}$

Regarding the first category, the law has evolved to provide purchasers of goods, and sometimes third parties, with two possible regimes under which they may seek recovery: tort law and contract law. Although tort law makes available actions due to negligence, the most significant tort theory open to plaintiffs is strict liability. ${ }^{107}$ In contract, the competing theory of

103. A useful example of this idea is provided by Professor James Rogers in his discussion of restitution and unjust enrichment. See James Steven Rogers, Restitution for Wrongs and the Restatement (Third) of the Law of Restitution and Unjust Enrichment, 42 WAKE ForEST L. REV. 55, 84 (2007). Rogers notes that as long as restitution is viewed as a parasitic doctrine (i.e., permitting recovery only when the conduct in question is characterized as wrongful by other law), courts will have an incentive to manipulate other law if existing legal categories of wrongful behavior do not quite fit. Id. He contends, for example, that courts often find abuses of fiduciary relationships by defendants, even though such findings are hardly supported by applicable law. Id. For further discussion of the judicial practice of strained characterization, see infra note 169 and accompanying text.

104. See, e.g., Scott Altman, Beyond Candor, 89 Mich. L. REv. 296, 328 (1990) (suggesting that "if judges more accurately revealed the forces that move them to decide, lawyers and commentators would be able more directly to address judges' real concerns"). One possible consequence of a legal system where outcomes turn on the uncertain categorization of fact patterns is the opportunities it affords judges to engage in covert policymaking: a world with many categories provides judges with many choices. Id. Concern that there are costs associated with judicial opinions in which the underlying reasoning is inaccurately stated or deliberately obscured is a persistent theme in the literature on judicial candor. $I d$.

105. See, e.g., Frederick Schauer, Formalism, 97 YALE L.J. 509, 542 (1988) (pointing out that "[r]ules stabilize by inflating the importance of the classifications of yesterday," leading to "inflexibility in the face of a changing future").

106. Indemnity Ins. Co. v. Am. Aviation, 891 So. $2 d 532$ (Fla. 2004).

107. A cause of action for negligence generally requires plaintiffs to establish that the manufacturer or seller has failed to use reasonable care to eliminate foreseeable dangers that 
significance is the implied warranty of merchantability. ${ }^{108}$ The economic loss rule seeks to carve out a separate niche for tort and warranty based on the type of damages involved. ${ }^{109}$ The rule's basic proposition is that when the purchaser of a product sustains economic loss without personal injury or damage to property, the purchaser must seek a remedy in contract, not in tort. ${ }^{110}$

The ostensibly straightforward nature of the economic loss rule in this context is belied by the confusion and conflicting case law it has spawned. Even the basic question of whether damages for injury to the property itself can be recovered in tort has yielded inconsistent answers. ${ }^{111}$ The poles are represented by the majority-or California-position (i.e., where a defective product causes only monetary damages, warranty liability

create an unreasonable risk of harm to the person or property of another. See RESTATEMENT (SECOND) OF TORTS $\S 395$ (1965). In the case of manufacturing defects and defendants that are not manufacturers, this may be impossible to do. Whereas negligence focuses on the actions of the defendant, a strict liability claim focuses on the product. Thus, it is not surprising that plaintiffs exhibit a preference for the latter theory, which is currently enshrined in the Restatement (Third) of Torts: Products Liability. Section 1 provides that "[o]ne engaged in the business of selling or otherwise distributing products who sells or distributes a defective product is subject to liability for harm to persons or property caused by the defect." Restatement (THIRD) OF ToRTs: Products Liability $\S 1$ (1998). Section 2 then proceeds to set forth three separate standards for determining whether a product is defective, depending on whether the claimed defect is (1) a manufacturing defect, (2) a design defect, or (3) a failure to warn or give adequate instructions. Id. at $\S 1$. For further discussion of the concept of defect, see infra notes 124-25 and accompanying text.

108. UCC Article 2 recognizes several "gap-filling" warranties that are part of the contract of the parties unless they are excluded or modified by agreement. Section 2-314 provides that if the seller is "a merchant with respect to goods of that kind," then "a warranty that the goods shall be merchantable is implied in a contract for their sale." U.C.C. $\S 2$ 314 (1) (2011). Determining the level of section 2-314 quality that is required by the term "merchantable" obviously calls for a fact-intensive inquiry guided by the criteria of section $2-314(2)(a)-(f)$. See id. at $\S 2-314(2)$ (a)-(f). The usual focus in a products liability case is whether the goods were "fit for the ordinary purposes for which such goods are used." Id. at $\S 2-314(2)$ (c). Because the warranty of merchantability is imposed on parties by law based on public policy, it looks strikingly similar to the tort doctrine of strict liability- hence, Prosser's colorful observation that implied warranty is "a freak hybrid born of the illicit intercourse of tort and contract." William L. Prosser, The Assault upon the Citadel (Strict Liability to the Consumer), 69 YALE L.J. 1099, 1126 (1960). In addition to the implied warranty of merchantability, a plaintiff may sometimes be able to claim a breach of an express warranty under section $2-313$ or the warranty of fitness for a particular purpose under section 2-315. Since these two warranties are not designed to address the basic safety of goods, they will be ignored in the discussion that follows.

109. Indemnity Ins. Co. v. Am. Aviation, 891 So. 2d 532, 536 (Fla. 2004).

110. Id.

111. See infra notes 112-15 and accompanying text. 
preempts the field) ${ }^{112}$ and the minority-or New Jersey-position (i.e., allowing tort recovery for injury to the product itself whether or not the defect created an unreasonable risk of harm). ${ }^{113}$ In between these two poles are intermediate positions, seeking to differentiate between, for example, "the disappointed users . . and the endangered ones," nature of the defect, the type of risk, and the manner in which the injury arose." 115

With two different avenues of relief potentially available to plaintiffs (tort and contract), uncertainty, unpredictability, and confusion often result when the two regimes compete. ${ }^{116}$ Maintaining the crucial distinction between the categories of tort and contract and the significance of applying one or the other necessitates that there be rule differences between the two regimes. And there are. For example, the measurement of damages may different, with only tort law permitting recovery of damages for pain and suffering and, in appropriate cases, punitive damages. In addition, under the contract regime only, the implied warranty of merchantability can be freely disclaimed $^{17}$ and remedies limited by including appropriate terms in the agreement of the parties. ${ }^{118}$ Another difference exists in the applicability of

112. See, e.g., Seely v. White Motor Co., 403 P.2d 145, 150-51 (Cal. 1965).

113. See, e.g., Santor v. A \& M Karagheusian, Inc., 207 A.2d 305, 308-10 (N.J. 1965).

114. See, e.g., Russell v. Ford Motor Co., 575 P.2d 1383, 1387 (Or. 1978).

115. See, e.g., Pa. Glass Sand Corp. v. Caterpillar Tractor Co., 652 F.2d 1165, 1173 (3d Cir. 1981).

116. This is not an original observation. See, e.g., Sundberg v. Keller Ladder, $189 \mathrm{~F}$. Supp. 2d 671, 676 (E.D. Mich. 2002) ("Although the separate action of 'implied warranty' had long co-existed with more formal product liability tort actions, it became duplicative and confusing."); RestatemENT (THIRD) OF TORTS: PRODUCTS LIABILITY $\S 2 \mathrm{cmt}$. n (1998) ("To allow two or more factually identical risk-utility claims to go to a jury under different labels, whether 'strict liability,' 'negligence,' or 'implied warranty of merchantability,' would generate confusion and may well result in inconsistent verdicts."); James J. White, Evaluating Article 2 of the Uniform Commercial Code: A Preliminary Empirical Expedition, 75 Мich. L. REv. 1262, 1270 (1977) ("[D]rafters . . . did not foresee the considerable potential for confusion between the Code provisions and such strict tort doctrines.").

117. See U.C.C. § 2-316 (2011).

118. It is not unusual for the contract to contain a clause that excludes recovery for consequential damages. See id. at $\S 2-719(3)$. Moreover, the buyer may agree to an exclusive remedy such as "repair and replacement of non-conforming goods or parts," which would effectively preclude the recovery of damages. $I d$. at $\S 2-719(1)(a)$. The approach of the Restatement (Third) of Torts: Products Liability is quite different:

Disclaimers and limitation of remedies by product sellers or other distributors, waivers by product purchasers, and other similar contractual exculpations, oral or written, do not bar or reduce otherwise valid products liability claims against sellers or other distributors of new products for harm to persons.

Restatement (ThIRD) OF ToRTs: Products Liability § 18 (1998). 
statutes of limitation: the warranty statute in contract begins to run at the time the goods are tendered, while in tort, the statute typically begins to run at the time of injury. Yet another difference is that, unlike breach of warranty actions in contract, tort actions require no privity of contract. ${ }^{119}$ Finally, notice of breach is a prerequisite to recovery in an action for breach of warranty, while no such notice is required to recover in tort. ${ }^{120}$

The foregoing differences between warranty claims and tort claims in many ways are justified as a reflection of the different policies that underlie the two categories. Contract law seeks to protect the economic expectations of the parties that have as their source the private allocation of risks and costs that arise from their agreement. In contrast, tort law is designed to accomplish a collective allocation of loss through the imposition of duties that arise from society's interest in the avoidance of harm, irrespective of the existence of a contract. The distinction between tort and contract therefore rests on the importance of the latter in promoting public safety and the need for the former to protect the expectations of contracting parties. ${ }^{121}$

At least as a general rule, these policy differences argue powerfully in favor of maintaining, at least to some extent, the two products liability regimes that currently exist. To be sure, one could argue that burdening a product liability case with the conceptual baggage of discrete liability regimes when the claim rests on the same factual predicate adds nothing but confusion and, therefore, consolidation of the two doctrinal categories of liability in and of itself would improve the current system. ${ }^{122}$ Without entering entirely into the fray about the strengths and weaknesses of complete consolidation, I wish to suggest that although tort theories of products liability and the implied warranty of merchantability coexist, the

119. See Restatement (Third) of Torts: Products Liability $\S 1 \mathrm{cmt}$. a (1998) ("Strict liability in tort for defectively manufactured products merges the concept of implied warranty, in which negligence is not required, with the tort concept of negligence, in which contractual privity is not required."). UCC Article 2 does contain a provision that extends a warranty made directly to a class of third parties not in privity with the warrantor. See U.C.C. § 2-318 (2011).

120. See U.C.C. $\$ 2-607(3)(a)(2011)$.

121. See, e.g., Spring Motors Distribs. v. Ford Motor Co., 489 A.2d 660, 672 (N.J. 1985) ("The purpose of a tort duty of care is to protect society's interest in freedom from harm, i.e., the duty arises from policy considerations formed without reference to any agreement between the parties. A contractual duty, by comparison, arises from society's interest in the performance of promises."); see also E. River S.S. Corp. v. Transamerica Delaval, 476 U.S. 858,870 (1986) ("[T] he failure of the purchaser to receive the benefit of its bargain [is] traditionally the core concern of contract law.").

122. Some courts have merged the doctrines of tort and contract liability because they are so intertwined. See, e.g., Hearn v. R.J. Reynolds Tobacco Co., 279 F. Supp. 2d 1096, 1103 (D. Ariz. 2003) ("[I]n Arizona, when a complaint alleges product liability claims under theories of both breach of implied warranties and strict liability, those theories merge."). 
coherence of each category does not necessarily require a different approach to every issue. ${ }^{123}$

The point can be made more vivid by examining the distinction between the defect concepts in tort law and those in implied warranty theory. In a personal injury or property damage case, whether the claim is based on negligence, breach of implied warranty, or strict liability, the product must be found to be unsafe (i.e., dangerous by some measure) to be actionable. There is simply no good reason why the relevant standard for determining whether a product is unsafe should not be the same under all three categories. Not surprisingly, the Restatement (Third) of Torts: Products Liability espouses this position, ${ }^{124}$ and the drafting committee that produced the now defunct amended U.C.C. Article 2 agreed. ${ }^{125}$

123. At least one court has ignored the characterization of a plaintiff's claim when deciding the applicable statute of limitations. See, e.g., Hambleton v. R.G. Barry Corp., 465 N.E.2d 1298, 1302 (Ohio 1984) ("[I]n determining which limitation period will apply, courts must look to the actual nature or subject matter of the case, rather than to the form in which the action is pleaded.").

124. A comment to section 2 of the Restatement states:

Warranty. Liability for harm caused by product defects imposed by the rules stated in this chapter is tort liability, not liability for breach of warranty under the Uniform Commercial Code (U.C.C.). Courts may characterize claims under this Chapter as claims for breaches of the implied warranty of merchantability. But in cases involving defect-caused harm to persons or property, a well-coordinated body of law dealing with liability for such harm arising out of the sale of defective products would adopt the tort definition of product defect.

Restatement (ThiRd) OF ToRTs: Products Liability $\S 2 \mathrm{cmt} . \mathrm{r}$ (1998).

125. See Amended U.C.C. $\$ 2-314 \mathrm{cmt} .7$ (2003). Amended Article 2 received final approval at both the 2002 annual meeting of the Uniform Law Commission and the 2003 annual meeting of the American Law Institute. Currently, there have been no state adoptions and the sponsoring organizations withdrew their support in 2011.

Case law on the approach to the question of whether proof that a product is "defective" under strict liability in tort will establish that a product is not merchantable, and vice versa has been mixed. Perhaps the leading case denying such congruency is Denny $v$. Ford Motor Co., 662 N.E.2d 730 (N.Y. 1995). In that case, the New York Court of Appeals opined that the question of design defect for purposes of strict liability is to be determined by application of a risk-utility balancing test that requires evaluation of a number of "policydriven factors," whereas the question of merchantability is to be decided according to whether the product satisfies ordinary consumer expectations. Id. at 735-36. For a contrary view, see Chestnut v. Ford Motor Co., 445 F.2d 967, 968 (4th Cir. 1971) ("The standard of safety of goods imposed on the seller or manufacturer of a product is essentially the same whether the theory of liability is labeled warranty or negligence or strict tort liability: the product must not be unreasonably dangerous at the time that it leaves the defendant's possession...."). 
Even if the considerations marshaled thus far show that overlap between tort and contract law may be desirable in some situations, and that barriers between the two categories need to be adjusted when it comes to establishing that a product defect exists, it does not follow that these two legal categories must also produce the same damages award. Countervailing considerations, some of them taken up below, make it easy to understand the continuing debate over the wisdom of maintaining remedial distinctions applicable in the two different substantive areas. But even if it can be shown that distinctions are appropriate in some contexts, I attempt to show that the basic arguments against a unified theory of damages are not decisive, and that a principle of congruence would improve the operation of our legal system by making damages awards more fair and efficient. ${ }^{126}$

To put this observation in context, consider, first, the economic loss doctrine and its rationale in situations where a contract is lacking. ${ }^{127}$ What explains the reluctance of tort law to provide redress when the interest that has been interfered with is of a purely economic nature unconnected with damage to the plaintiff's person or property? The rule's basic utility that it operates as an administratively manageable control mechanism for dealing with the problems caused by the inordinate liability that might otherwise result if economic loss were permitted, especially in cases involving large scale disasters. In this regard, the warning of Fifth Circuit Judges Clark and Gee in an economic loss case arising out of a collision between two ships in the Mississippi River Gulf outlet is particularly pertinent:

An oil spill damages hundreds, perhaps thousands, of miles of coastal area. A cloud of noxious industrial gas leaks out, kills thousands, and injures thousands more. A commonly-used building material is discovered, years after the fact, to possess unforeseen lethal qualities affecting thousands who have worked with it . . . [T] [Te disputeresolution systems of courts are poorly equipped to manage disasters of such magnitude and ... we should be wary of adopting rules of decision

126. This view has been expressed by others in other contexts. See, e.g., Paul T. Wangerin, Damages for Reliance Across the Spectrum of Law: Of Blind Men and Legal Elephants, 72 lowa L. REv. 47, 99 (1986) ("One set of facts can lead to three, four, or maybe even five separate claims. But, as such multiple theories reach the courts with greater frequency, the courts themselves will soon realize that some consistent theory must evolve to govern damages awards. A fair system of law, these courts will acknowledge, must produce the same damages awards for relying promisees regardless of whether those promisees sue asserting contract, agency, tort, insurance, or restitution theories. Consistency must be achieved.").

127. In those situations where there is no contract, the rule cannot be defended on the ground that economic losses are generally best allocated via contract. The force of this defense is particularly evident when the contract disclaims the warranty of merchantability or limits remedies for breach. See supra notes 117-18 and accompanying text. 
which, as would that contended for by the dissent, encourage the drawing of their broader aspects before us. ${ }^{128}$

But if this is the modern rationale for the rule, it is apparent that considerable thought ought to be given to restructuring it. Resting the tortfeasor's liability for economic loss on whether there was corresponding personal injury or property damage seems undesirable because (1) it lets an all-or-nothing damages decision ride on a factor that is not finely geared to preventing excessive liability for accidental injuries, (2) it is an unnecessary constraint on liability in light of other existing tort doctrines, and (3) it can lead to outcomes that are logically inconsistent with the remedial goals of tort law. ${ }^{129}$

Professor Silverstein illustrates the first objection with the following hypothetical:

[I]f negligent maintenance of a utility transformer causes a telephone pole to lop the chimney from a factory's roof, the utility must bear the costs of repair; if the falling telephone pole separates a person's little finger from her left hand, the utility is liable for her medical expenses, pain and suffering, and lost income. Indeed, if the lopped off chimney costs the factory a few days of production, or if the separated finger causally disables an investor from effecting a FAX transmission authorizing a sale

128. State of Louisiana v. M/V Testbank, 752 F.2d 1019, 1032 (5th Cir. 1985) (Clark, C.J. and Gee, J., concurring); see also Barber Lines A/S v. M/V Donau Maru, 764 F.2d 50, 55 (1st Cir. 1985) (then-Judge Breyer expressed concern that "liability for pure financial harm, insofar as it proved vast, cumulative and inherently unknowable in amount, could create incentives that are perverse."). In a case involving an investor's claim against an accounting firm for negligently certifying a balance sheet, Justice Cardozo had a similar reaction to the threat of widespread liability:

If liability for negligence exists, a thoughtless slip or blunder, the failure to detect a theft or forgery beneath the cover of deceptive entries, may expose accountants to a liability in an indeterminate amount for an indeterminate time to an indeterminate class. The hazards of a business conducted on these terms are so extreme as to enkindle doubt whether a flaw may not exist in the implication of a duty that exposes to these consequences.

Ultramares Corp. v. Touche, 174 N.E. 441,444 (N.Y. 1931).

129. The economic loss doctrine is not without its fair share of critics. See, e.g., Eileen Silverstein, On Recovery in Tort for Pure Economic Loss, 32 U. MICH. J.L. REFORM 403, 438 (1999) (arguing that "the categorical denial of the right to recover for pure economic injury does positive injustice to our understanding of the significance of material insecurity and economic integrity in American society"); see also Fleming James, Jr., Limitations on Liability for Economic Loss Caused by Negligence: A Pragmatic Appraisal, 25 VAND. L. REV. 43, 46-47 (1972) (arguing that a logical inconsistency exists between the rules governing economic recovery under personal injury and non-physical injury). 
of stock worth $\$ 2$ million, both losses are recoverable because they are attendant on negligently inflicted damage to person (the broken finger) or property (the damaged chimney). But if, instead of amputating a finger or a chimney, the downed telephone pole merely causes the interruption of a communication authorizing the stock transaction, the investor, not the utility company, must bear the $\$ 2$ million loss; and if the damaged chimney causes the factory to suspend operations for a few days, while the utility is responsible to the factory owner for repairs and lost profits, it is not responsible to the factory employees for lost wages, since the employees experienced no physical impairment of their property or persons. ${ }^{130}$

It should be obvious that the economic loss rule's achievement of the advantages of controlling the dimensions of the problems that could arise from large-scale disasters is, at best, fortuitous. If the telephone pole falls to the left and causes even a small amount of damage to the factory building, the barrier to economic loss recovery is lifted, regardless of its amount. If, however, the pole falls to the right and leaves the building unscathed, the negligently inflicted losses must be born in full by the owners. If the fear is of imposing a "liability in an indeterminate amount for an indeterminate time to an indeterminate class," whether a plaintiff was injured in a particular way, but not attend to the magnitude of the loss? On this latter dimension-obviously critical to the accepted rationale for the historical reluctance to award damages for pure financial harm-the economic loss rule has nothing to say. If the rule were truly finely geared to respond to the law's concern with indeterminate liability, it would place its emphasis on the magnitude of damages involved, not the form that those damages take. ${ }^{132}$

Of course, the rule may be defended on purely administrative convenience grounds. Even if it is a poor reflection of the law's overriding concern for avoiding unlimited liability for negligently engaging in a socially desirable activity, it does operate as a bright-line rule that can be administered with little difficulty, and does to some extent avoid the flood of litigation that would likely ensue if the rule were abandoned. ${ }^{133}$ Indeed,

130. Silverstein, supra note 129 , at 404.

131. Ultramares Corp., 174 N.E. at 444

132. Another illogical aspect of the economic loss rule is its refusal to recognize property damage as just another form of economic loss. See Silverstein, supra note 129, at 434 (recognizing that "damage to property is often nothing more (or less) than economic loss"). Professor Silverstein also questions the coherency of permitting recovery for pain and suffering but not pure economic loss. As she puts it, "[i]t is ironic, of course, that conditions not measurable in money are allowable damages while consequences like economic loss, measurable only in money, may be deemed immune from recovery." Id. at $436 \mathrm{n} .163$.

133. As one commentator has noted, "only a limited amount of physical damage can ever ensue from a single act, while the number of economic interests a tortfeasor may 
the majority in $M / V$ Testbank, while conceding that there is often a certain arbitrariness of result, nevertheless praises the rule's administrative simplicity: "[W]hen lines are drawn sufficiently sharp in their definitional edges to be reasonable and predictable, such differing results are the inevitable [result] . . . ${ }^{\prime 134}$ But is the majority correct? Is application of the rule as simple as it assumes? As criticism of the rule has grown, some courts have complicated matters by recognizing numerous exceptions to its application. ${ }^{135}$

The difficulties inherent in the economic loss rule are well illustrated in the Eastern District of Virginia case of Pruitt $v$. Allied Chemical Corp. ${ }^{136}$ There the defendant manufactured and eventually dumped thousands of pounds of Kepone, a highly toxic pesticide, into the Hopewell, Virginia sewerage treatment plant. ${ }^{137}$ When this dumping activity was discovered, the State of Virginia ordered portions of the James River and the Chesapeake Bay closed to fishing. ${ }^{138}$ Pruitt was one of several legal actions that were commenced as a result of these events. The plaintiffs fell into three different groups: (1) commercial fishermen, shellfishermen, and oysterbed lessors; ${ }^{139}$ (2) wholesale and retail seafood enterprises not themselves engaged in fishing operations, including restaurants; ${ }^{140}$ and (3) operators of marinas and owners of boats and owners of tackle and bait shops. ${ }^{141}$ In addition to pressing their own claims, this latter group was also permitted to act as surrogates for the claims of recreational fishermen. ${ }^{142}$

The complexity of the legal issues involved is best revealed in Judge Merhige's analysis of the rights of the commercial fisherman to recover for all lost profits caused by a decline in demand for what the public believed might be tainted seafood. ${ }^{143}$ The plaintiffs had to overcome both the

destroy in a brief moment of carelessness is practically limitless." Comment, Foreseeability of Third-Party Economic Injuries - A Problem in Analysis, 20 U. CHI. L. REV. 283, 298 (1953). This may be true, but I question whether the economic loss rule is best suited to serve the particular function of limiting claims. See infra notes 155-71 and accompanying text.

134. State of Louisiana v. M/V Testbank, 752 F.2d 1019, 1029 (5th Cir. 1985).

135. For many of exceptions to the rule, see W. PAGE KeETON ET AL., Prosser AND KEETON ON THE LAW OF TORTS 707-10 (W. Page Keeton ed., 5th ed. 1984).

136. Pruitt v. Allied Chem. Corp., 523 F. Supp. 975 (E.D. Va. 1981).

137. Andrew W. McThenia \& Joseph E. Ulrich, A Return to Principles of Corrective Justice in Deciding Economic Loss Cases, 69 VA. L. REv. 1517, 1518 (1983).

138. Id. at 1518 n.5.

139. See Pruitt, 523 F. Supp. at 976.

140. See id. at 979 n.20.

141. See id. at 980 n.23.

142. Id. at 980 .

143. Because the only point I am trying to make here is that those who insist that the economic loss rule is a rule of administrative simplicity leading to predictable results are oversimplifying the rule's application, I will ignore the other aspects of the case. For the best 
Restatement and traditional precedent-based arguments that would deny recovery in cases of this kind. ${ }^{144}$ In addition to case law from other jurisdictions that would require plaintiffs to show an injury to a property interest in the fish or fishing grounds, they had to contend with the decision of the Fourth Circuit in Marine Navigation Sulphur Carriers, Inc. v. Lone Star Industries, Inc. ${ }^{145}$ a case brought by commercial parties to recover for business losses resulting from the closure of the James River to marine traffic after the defendants' vessel struck a bridge. ${ }^{146}$ In that case, the Fourth Circuit held that because plaintiffs could not show damage to their property or person, they could not recover. ${ }^{147}$ In concluding that the economic loss rule barred recovery, the Fourth Circuit refused to adopt the Ninth Circuit's decision in Union Oil Company v. Oppen. ${ }^{148}$ In that case, the Oppen court allowed the claims of commercial fishermen damaged by an oil spill on the purely pragmatic ground that it would help foster environmental protection policies. ${ }^{149}$ The Marine Navigation court rejected the Oppen oil pollution exception as applying to its own factual situation. ${ }^{150}$ In other words, it had no application to claims for economic losses not deriving from harm to marine life caused by an event that implicates environmental concerns. ${ }^{151}$

Within the framework of the foregoing distinction between Marine Navigation and Oppen, Judge Merhige could have justified recovery for the fisherman by concluding that the case before him was factually more closely aligned with the latter than the former. The acceptability of this justification in turn rests on accepting the irrelevance of the distinction that in Oppen, fish died; whereas in Pruitt, the fish survived, but demand declined. ${ }^{152}$ Indeed, it was this distinction that the defendant relied upon to support its contention that the plaintiffs' claims should fail. ${ }^{153}$ Judge Merhige did not directly assess the strength of these competing arguments, instead concluding that Allied's concession that the fisherman would be entitled to recover lost profits for actual destruction of the fishery was

and most comprehensive discussion of Pruitt, see McThenia \& Ulrich, supra note 137.

144. See Pruitt, 523 F. Supp. at 977; ResTATEMENT (SECOND) OF TORTS $\S 766 C$ (1979).

145. Marine Navigation Sulphur Carriers, Inc. v. Lone Star Indus., 638 F.2d 700 (4th Cir. 1981).

146. Id. at 701; McThenia \& Ulrich, supra note 137 , at 1525.

147. Id. at 702 .

148. See id. at 701; Union Oil Co. v. Oppen, 501 F.2d 558 (9th Cir. 1974).

149. See Oppen, 501 F.2d at 570.

150. See Marine Navigation, 638 F.2d at 701.

151. See id. at 701-02.

152. The fishermen were able to catch their quota of fish, but their customers refused to pay normal prices for what they considered to be tainted seafood. See McThenia \& Ulrich, supra note 137, at 1527 n.51 (citing Brief in Support of Motion for Partial Summary Judgment at 5-6, Pruitt v. Allied Chem. Corp., 523 F. Supp. 975 (E.D. Va. 1981) (Civ. A. No. 77-0035-R)).

153. Id. 
tantamount to a showing of a property right or interest in the fish. ${ }^{154}$ While the decision was a clear win for the commercial fishermen, there is obviously some difficulty in finding legal support for this bit of alchemy. It is hard to accept the proposition that those whose business it is to fish have any type of property interest in fish that have not yet been caught. One can surmise that although Judge Merhige was attracted by the perceived benefits of the economic loss rule, he nevertheless sought an approach that would allow the fisherman to recover. As his opinion demonstrates, he found such an approach. Recovery was permitted and, at the same time, Judge Merhige was able to insist that the law only protects a plaintiff whose person or property is physically injured.

It is a central dogma of the economic loss rule that its rationale can be adequately explained as a simple way of controlling the possible flood of litigation which might otherwise ensue from large scale disasters. My point above is that the rule's application is not necessarily simple. The question now is whether it is necessary. To suggest an answer to this question prompts reflection on some general features of tort law.

The classic case of Kinsman Transit Co. v. City of Buffalo provides a convenient vehicle for examining several of the doctrinal devices that have served to limit liability. ${ }^{155}$ The unfortunate chain of events in this case began when the defendants allegedly caused a vessel to break loose from her moorings. ${ }^{156}$ The vessel then careened down the Buffalo River and struck a second vessel which in turn broke loose from her moorings. ${ }^{157}$ Together, both vessels drifted further downstream, eventually crashing into and collapsing the Michigan Avenue Bridge. ${ }^{158}$ The two vessels, together with the wreckage from the bridge, formed a dam which caused extensive flooding and an ice jam. ${ }^{159}$ As a result of this disaster, one plaintiff, the owner of cargo stored on a vessel berthed below the Michigan Avenue Bridge, sought to recover damages resulting from its inability to unload the cargo directly into its grain elevators located above the collapsed bridge. ${ }^{160}$ A second plaintiff had a somewhat different claim. At the time these events transpired it was engaged in unloading cargo from a vessel above the bridge. Apparently, this vessel was struck by one of the two vessels floating down the river, causing it to break loose from the dock to which it was moored and get stuck in the ice jam. The upshot of all this was that special equipment had to be rented to continue with the unloading. ${ }^{161}$

154. Pruitt, 523 F. Supp. at 978.

155. Kinsman Transit Co. v. City of Buffalo, 388 F.2d 821 (2d Cir. 1968).

156. Id. at 822 .

157. Id.

158. Id.

159. Id. at 823 .

160. Id.

161. Id. 
The court's opinion here contained a concise exposition of why liability-limiting devices are needed: "Such limiting principles must exist in any system of jurisprudence for cause and effect succeed one another with the same certainty that night follows day and the consequences of the simplest act may be traced over an ever-widening canvas with the passage of time.",162

Courts faced with the problem of catastrophic liability often make use of one or more flexible concepts-proximate cause, ${ }^{163}$ duty ${ }^{164}$ and foreseeability ${ }^{165}$ - that can be used to draw the line between whether or not legal responsibility exists for the harm that has in fact occurred to the plaintiff's interests. In Kinsman, the court proceeded on the assumption that the defendants could reasonably foresee the consequences that would follow from their negligence. ${ }^{166}$ Thus, if the court were to hold that the defendants were not accountable, that assumption would require it to make an instrumental shift in orientation. If the tort concepts that limit liability are conveniently put aside, the legal responsibility question can be approached on explicit policy grounds. Indeed, the court opined that " " $[i] t$ is all a question of expediency ... of fair judgment, always keeping in mind the fact that we endeavor to make a rule in each case that will be practical and in keeping with the general understanding of mankind."'167 The court ultimately denied recovery on the ground that "the connection between the defendants' negligence and the claimants' damages [was] too tenuous and remote. ..."

162. Id. at 824 .

163. See KeETON ET AL., supra note 135, at 273 ("The term 'proximate cause' is applied by the courts to those more or less undefined considerations which limit liability even where the fact of causation is clearly established.").

164. Id. at 274 ("It is quite possible to state every question which arises in connection with 'proximate cause' in the form of a single question: was the defendant under a duty to protect the plaintiff against the event which did in fact occur? Such a form of statement does not, of course, provide any answer to the question, or solve anything what ever ....").

165. Id. at 280-81 ("At the risk of becoming wearisome, it must be repeated that the question [of foreseeability] is primarily not one of causation, and never arises until causation has been established. It is rather one of the fundamental policy of the law, as to whether the defendant's responsibility should extend to such results.").

166. See Kinsman, 388 F.2d at 824.

167. Id. at 825 (quoting Judge Andrews' statement in Palsgraf v. Long Island R.R., 248 N.Y. 339, 354-55 (N.Y. 1928)).

168. Id. To further explain its conclusion, the court offered the following illustration:

To anyone familiar with N.Y. traffic there can be no doubt that a foreseeable result of an accident in the Brooklyn Battery Tunnel during rush hour is that thousands of people will be delayed. A driver who negligently caused such an accident would certainly be held accountable to those physically injured in the crash. But we doubt that damages would be recoverable against the negligent driver in favor of truckers 
The conclusions of proximate cause, duty, and foreseeability are, therefore, perhaps best understood as a covert policy judgment on the issue of liability, based upon the fear of exposing the defendant to unknowable, catastrophic liability. But as Professor Karl Llewellyn so famously put it: "Covert tools are never reliable tools." 169 One justification for the economic loss rule may be that it minimizes costs by providing courts with a less problematic alternative for protecting against unreasonable risk. Nevertheless, support for the economic loss rule based solely on the indeterminacy of the various tort concepts misses the more salient point that the rule serves as an absolute bar to recovery, even in those instances where policy considerations might otherwise lead us to conclude that the defendant should be legally responsible. In other words, why should we maintain a rule that consistently benefits wrongdoers at the expense of those who are victimized by the consequences of the wrongdoer's actions? $?^{170}$ The emphasis should rest on the extent to which the imposition of liability is consistent with the instrumentalist and other goals of tort law, notwithstanding the fact that this sort of analysis cannot be applied with mathematical precision. ${ }^{171}$ The familiar tort concepts that currently serve to

or contract carriers who suffered provable losses because of the delay or to the wage earner who was forced to "clock in" an hour late. And yet it was surely foreseeable that among the many who would be delayed would be truckers and wage earners.

Id. at $825 \mathrm{n} .8$.

169. K.N. Llewellyn, 52 HARV. L. Rev. 700, 703 (1939) (book review). Llewellyn wrote this in connection with his discussion of the willingness of courts to perceive the unfairness of a particular clause or contract and attempt to rectify it through misconstruction of contract language or misapplication of particular doctrines. Evidence suggests that section 2-302 of the Uniform Commercial Code ("Unconscionable Contract or Term") emerged from Llewellyn's own calculus of the costs and benefits associated with what he perceived to be the less than forthright manner in which courts reacted against harsh contractual provisions. See Arthur Allen Leff, Unconscionability and the Code: The Emperor's New Clause, 115 U. PA. L. REV. 485, 525-27 (1967).

170. This point was made in a dissenting opinion from Louisiana ex rel. Guste v. $M / V$ Testbank, 752 F.2d 1019, 1052 (5th Cir. 1985) (Wisdom, J., dissenting) (stating "absent hard data, I would rather err on the side of receiving little additional benefit from imposing additional quanta of liability than err by adhering to Robins' inequitable rule and bar victims' recovery on the mistaken belief that a 'marginal incentive curve' was flat, or nearly so. If a loss must be borne, it is no worse if a 'merely' negligent defendant bears the loss than an innocent plaintiff absorb the damages.").

171. One such case is Kinsman, and People Express Airlines, Inc. v. Consolidated Rail Corp., 495 A.2d 107 (N.J. 1985), is another. There, the court declined to apply the economic loss rule to prevent recovery of losses by an airline when forced to evacuate its terminal following the negligent release of a chemical from a nearby railroad car. Instead, the court held that an obligation of due care would exist if a plaintiff could establish "particular foreseeability," a standard calling for a case-by-case inquiry. Id. at 116 . It had this to say 
limit liability have, therefore, an obvious attraction. In sum, their imprecision, together with ambiguity in the case law, enable courts to discern and reach appropriate results generally. This is something that the economic loss rule is incapable of doing.

Let us now return to the specific question of whether lost time claims should be cognizable under the law of negligence. Once we recognize that the economic loss rule should not bar such claims, it becomes apparent that permitting such recovery is supported by those same considerations that justify tort damages generally. Courts and commentators seeking to provide normative criterion for the remedial structure of tort law typically fall into two groups. In one group are the adherents of law and economics, who argue that the remedial structure should be designed so as to create efficient incentives. ${ }^{172}$ In the other group, we find the supporters of corrective justice, who stress the non-instrumentalist goal of compensating the victims of wrongdoing. ${ }^{173}$

Now consider how the two groups would pursue their respective goals if presented with a claimant who was wrongfully deprived of leisure time. In this regard, it is important not to lose sight of the simple fact that the claimant has suffered a real loss. From the perspective of law and economics, the key is to deter non-cost-justified accidents by creating incentives for actors to behave more carefully in the future. That is, liability for negligence should be imposed in those instances where the costs to the victim were greater than the benefits to the actor. In this respect, it is essential that the actor internalize the costs of her behavior if we expect to see an optimal investment in precautions designed to avoid torts. It is only then that the tort system can deter excessively risky activity in the future. ${ }^{1 / 4}$

about the economic loss rule:

Whatever the original common law justifications for the physical harm rule, contemporary tort and negligence doctrine allow-indeed, impel - a more thorough consideration and searching analysis of underlying policies to determine whether a particular defendant may be liable for a plaintiff's economic losses despite the absence of any attendant physical harm.

Id. at 111 .

172. See, e.g., John C.P. Goldberg \& Benjamin C. Zipursky, Tort Law and Moral Luck, 92 CoRnell L. REV. 1123, 1141 n.58 (2007) (suggesting that law and economics dominates current discussions of tort law).

173. See generally Jules Coleman, Tort Law and the Demands of Corrective Justice, 67 IND. L.J. 349 (1992) (discussing the overall concept of corrective justice); Ernest Weinrib, Corrective Justice, 77 IowA L. REV. 403 (1992) (same).

174. See, e.g., Richard Posner, Some Uses and Abuses of Economics in Law, 46 U. CHI. L. REv. 281, 305 (1979) ("One of the main purposes of law, from an economic standpoint, is the control of externalities. . . Property rights and liability rules ... are devices by which people are given incentives to internalize the costs and benefits of their actions so that an 
This instrumental objective of tort law cannot be achieved if the loss of leisure time that results from wrongful activity is not reduced to a monetary value in comparing it to what must be done to reduce the risk that that form of loss might occur. Only then would the right amount of deterrence be produced by compelling negligent injurers to make good the victim's losses.

Corrective justice, on the other hand, is indifferent to the economic consequences of liability but is concerned with the injustice that results if a wrong has been committed and the wrong is not "corrected" by imposing on the wrongdoer a duty to compensate the victim. ${ }^{175}$ Presumably, a policy of compensating tort victims for losses would not be fostered by the failure to take account of lost leisure time. If compensation is the objective, then the damages awarded to a victim should equal the value of what he has lost. While it is true that damages for lost leisure time cannot truly "compensate" in the same way that damages for pecuniary losses can, ${ }^{176}$ the principle of corrective justice suggests that courts should provide recovery for this very real loss. Failure to do so would almost certainly produce undercompensation.

In its discussion of the cases cited by the plaintiff, the Hannaford court speaks in terms which seem singularly curious. These particular cases allowed recovery for lost time where the intention to harm was present. This leads the court to announce that "[b]ecause liability is often more extensive in cases of intentional torts than those in negligence, intentional tort cases recognizing recovery for time and effort have little bearing on our

efficient allocation of resources is achieved.").

175. The corrective justice view has been described as follows:

The traditional view-largely unchallenged until recent years-was to look at the law of torts as a study in corrective justice, as an effort to develop a coherent set of principles to decide whether this plaintiff was entitled to compensation from this defendant as a matter of fairness between the parties. Issues of public policy and social control were of course not absent, but they did not dominate judicial or academic attitudes either to particular cases or to general theory.

C. Gregory, H. Kalven, \& R. Epstein, Cases and Materials on Torts xxii (3d ed. 1977) (emphasis in original).

176. Damages for pecuniary losses can enable the victim to replace what was lost. For example, if property is damaged, money can be used to make repairs or purchase a replacement. Damages for lost leisure time cannot achieve this result. When time is lost, it is lost forever and no amount of money can actually provide for its replacement. In this sense, lost leisure time damages share common ground with nonpecuniary damages for pain and suffering. Neither recovery really makes the victim whole. See Louis L. Jaffe, Damages for Personal Injury: The Impact of Insurance, 18 LAW \& CONTEMP. PROBS. 219, 222-24 (1953) (suggesting that damages for pain and suffering provide only consolation or solatium). 
analysis. ${ }^{177}$ To justify its conclusion, the court misplaces its reliance on two cases. ${ }^{178}$ In the first, the intentional nature of the defendant's conduct formed no part of the plaintiff's prima facie case for damages, but became relevant only as a means to override a valid affirmative defense of charitable immunity. ${ }^{179}$ The second case involved a claim for mental distress, a type of harm for which courts have long exhibited a reluctance to allow recovery. ${ }^{180}$ The objections to permitting legal redress for emotional harm, though, do not necessarily counsel against recovery when negligence results in lost time. One obvious difference between the two types of claims supporting this conclusion is that lost time is far more difficult to falsify or imagine.

The position that liability should sometimes be more extensive in cases involving intentional harm is sometimes defended on the instrumentalist ground that there is an increased risk of an erroneous judgment if liability can be based on something as equivocal as careless behavior. This risk may have the untoward effect of creating the wrong incentives. Thus, some activities may be deterred that are not worth deterring. ${ }^{181}$ The problem with this argument rests in its failure to recognize that not all legitimate claims should be barred because a problem of proof may permit a certain percentage of illegitimate claims to succeed. Indeed, such an argument proves too much. A fear that the tort of negligence will yield false positives could be used to override the tort, no matter what the loss. Once it is settled that there is a tort of negligence for whatever reasons, it is impossible to see why the plaintiff should be denied a damages claim that she would otherwise have if the action lay because the harm inflicted was deliberate. Both intentional wrongs and negligent ones present equal occasions for

177. In re Hannaford Bros. Co. Customer Data Sec. Breach Litig., 4 A.3d 492, 497 (Me. 2010).

178. Id.

179. See Picher v. Roman Catholic Bishop of Portland, 974 A.2d 286 (Me. 2009).

180. See Garland v. Roy, 976 A.2d 940 (Me. 2009). See generally KEETON ET AL., supra note 135, at 54-66 (discussing claims for the infliction of mental distress).

181. For example, Professor Perlman writes that:

[A]s the amount of potential liability increases, an actor must attach greater significance to the risk that the substantive legal rule will be applied erroneously or that he mistakenly will cross the line from no liability to liability. This increased cost of error may inhibit socially useful activity. The problem is most acute where liability is based on negligence, because the line between careless and careful behavior is ambiguous. Courts thus tend to delimit liability more strictly for negligence than for intentional torts, where in many instances the line between lawful and unlawful behavior is clear.

Harvey S. Perlman, Interference with Contract and Other Economic Expectancies: A Clash of Tort and Contract Doctrine, 49 U. CHI. L. REv. 61, 70-71 (1982). 
corrective justice. In other words, the moral culpability of the wrongdoer should be irrelevant.

To illustrate, take first the following hypothetical suggested by Professor Prosser:

Suppose a custodian, whose duty it is to lock up a library at 10 o'clock to keep people out, decides to lock it up at 9 o'clock instead, and locks in those who refuse to leave. Is there any doubt that it is false imprisonment? ${ }^{182}$

And because it is the intentional tort of false imprisonment, the plaintiff is entitled to damages, including compensation for lost time. ${ }^{183}$ Now suppose the custodian has no actual knowledge that there are still patrons inside the library, but he could easily have eliminated the risk of accidently locking someone inside by a quick walk through the building or by a loud shout announcing the early closing. If we assume that the custodian has acted negligently in not taking these precautionary steps and that one or more persons are imprisoned as a result, the Hannaford court would nonetheless deny damages for lost time. The harm to those who are forced to spend the night in the library is as before, except that the element of intention is lacking. The same goals of tort law apply regardless of which of the causal paradigms - be it intentional or negligent interference with the plaintiff's person-is applicable to the defendant's conduct.

The foregoing observations about the recovery of lost time damages in tort leads to the related proposition that these damages should also be recoverable in contract. ${ }^{184}$ Once again, we are seeking damages rules that are both fair and efficient. The typical remedy for breach of contract is money damages ${ }^{185}$ in an amount sufficient to place the aggrieved party in as good a position as it would have been in had the contract been performed, ${ }^{186}$ or, as is frequently said, to give the aggrieved party "the benefit of its bargain." 187 This full compensation principle will usually be regarded as fair because, at least in theory, it provides an adequate performance

182. KEETON ET AL., supra note 135 , at 53 n. 72 .

183. See, e.g., Young v. Gormley, (Iowa 1903); Hewlett v. George, 9 So. 885 (Miss. 1891); Goodell v. Tower, 58 A. 790 (Vt. 1904).

184. Those who reject the idea that lost time should be viewed as a cognizable harm in a breach of contract action may justify their position on the ground that the amount involved is too speculative. This Article will later demonstrate that the case for their recognition can be made in simple and direct terms. See infra notes 196-221 and accompanying text.

185. Because of the difficulties in forcing people to continue a relationship that they no longer wish to continue, the law of contracts permits parties to compel performance of promises through legal means only in those instances when monetary damages are unsuitable. See RESTATEMENT (SECOND) OF CONTRACTS ch. 16, intro. n. at 100 (1981).

186. See id. at § 344(a); U.C.C. § 1-305(a) (2004).

187. RESTATEMENT (SECOND) OF CONTRACTS $\$ 344(\mathrm{a}) \mathrm{cmt}$. a (1981). 
substitute for the aggrieved party. Furthermore, it is economically efficient because of its incentive effects. The central economic concept that emerges from a consideration of incentives is that of "efficient breach."188

Without entering into the fray about the strengths and weaknesses of the theory of efficient breach, I will make a few points about its relation to compensation. ${ }^{189}$ According to this theory, incentives for performance are efficient if they compel a promisor to balance the cost to him of performing against the losses to himself and to the promisee that will result if he does not perform. ${ }^{190}$ This would correctly encourage breach only if the value of the gain to the promisor is greater than the value of the loss to his counterparty. ${ }^{191}$ If, on the other hand, the promisor's liability for damages was greater than any benefit to be gained from breaching the contract, presumably the promisor would elect to perform the contract instead. ${ }^{192}$ The chosen result (breach or performance) is defended on the ground that a "Pareto-superior" allocation of resources results because promisors would be encouraged to direct their efforts to the most valued use. ${ }^{193}$ If aggrieved promisees are systematically undercompensated, promisors would not internalize the full value of performance to the promisee and risk too much breach. ${ }^{194}$ Of course, overcompensation would have just the opposite result. ${ }^{195}$

188. See generally Richard A. POSNER, ECONOMIC ANALYSIS OF LAW 118-31 (7th ed. Aspen 2007).

189. For discussions of various criticisms of the efficient breach theory, see, e.g., Daniel Friedman, The Efficient Breach Fallacy, 18 J. LEGAL STUD. 1 (1989); Ian R. Macneil, Economic Analysis of Contractual Relations: Its Shortfalls and the Need for a "Rich Classificatory Apparatus," 75 Nw. U.L. REv. 1018 (1981).

190. See POSNER, supra note 188, at 118-31.

191. See id.

192. For judicial expressions of this idea, see, e.g., Patton v. Mid-Continent Sys., 841 F.2d 742, 750 (7th Cir. 1988) ("Even if the breach is deliberate, it is not necessarily blameworthy. The promisor may simply have discovered that his performance is worth more to someone else. If so, efficiency is promoted by allowing him to break his promise, provided he makes good the promisee's actual losses."); Giampapa v. Am. Family Mut. Ins. Co., 64 P.3d 230, 251 (Colo. 2003) ("The theory of 'efficient breach' posits that the purpose of contract law is not to discourage all breaches. To the contrary, certain breaches, such as those where the breaching party's gains exceed the injured party's losses, are thought to be desirable.").

193. In addition to producing an efficient allocation of resources, full compensation also has the added benefit of encouraging reliance on contract rights because, breach or no breach, the promisee knows that she will receive the benefit of her bargain.

194. See William S. Dodge, The Case for Punitive Damages in Contracts, 48 DuKE L.J. 629,664 (1999) ("If the breaching party is not responsible for the nonbreaching party's full loses, then there is an incentive to breach even when the breach would not be efficient.").

195. This notion accords remarkably with the historical unwillingness of courts to award punitive damages in breach of contract actions. See RESTATEMENT (SECOND) OF 
In sum, the failure of courts to award damages for lost leisure time involves more than issues of fairness and adequate compensation. There is also the possibility that this applied rule of damage recovery generates inefficient incentives to breach or go forward with contract performance, or to optimally invest in precautions to avoid torts. Providing compensation for lost time would eliminate this source of inefficiency.

\section{The Problem of Measurement}

Given the fact that the Hannaford court discounted other cases finding loss of time to be a cognizable injury because those cases failed to demonstrate how those damages were being measured, ${ }^{196}$ it is next relevant to inquire how the damage structure might integrate such a claim. The crux of the analysis that follows is that, although the measurement of unconventional forms of loss is often difficult, the substitution of market time for leisure or nonmarket time can provide a solution consistent with the rules of damages assessment.

Frequently, courts have stated that if the plaintiff fails to prove his damages "with reasonable certainty," all recovery is denied. ${ }^{197}$ For example, courts have asserted that the profits lost by a new business are too speculative to permit their recovery. ${ }^{198}$ In applying the reasonable certainty rule's higher standard of proof, however, courts have countenanced a departure from theory in several categories of litigation where the plaintiff's proof is as precise and accurate as the situation permits. ${ }^{199}$ Perhaps the most

CoNTRACTS $\S 353$ (1981). But see Dodge, supra note 194, at 663 ("Allowing a party to breach a contract and pay damages is not as efficient as forcing that party, with the threat of punitive damages, to negotiate with the other party for a release from the contract.").

196. In re Hannaford Bros. Co. Customer Data Sec. Breach Litig., 4 A.3d 492, 497 (Me. 2010).

197. See DoBbs, supra note 79, at 149-50. The effect of this rule is "to increase the injured party's burden of persuasion well beyond the usual one of making out his case by the 'preponderance or greater weight of the evidence." E. Allan Farnsworth, Legal Remedies for Breach of Contract, 70 COLUM. L. REV. 1145, 1210-11 (1970).

198. See DoBBS, supra note 79, at 154-55. But it would seem that a strong public policy underlying the substantive law involved may affect the degree of certainty required. Thus, the Supreme Court has permitted a theater owner to recover lost profits resulting from defendant's anti-trust violations even though there was great uncertainty regarding their amount. See generally Bigelow v. RKO Radio Pictures Inc., 327 U.S. 251 (1946).

199. See DOBBS supra note 79, at 151 ("[T] he plaintiff is probably expected to prove his damages with as much accuracy as is reasonably possible to him, but precision not attainable in the nature of the claim and circumstances is not ordinarily required."). As one English court fancifully put it:

As much certainty and particularity must be insisted on . . a as is reasonable, having regard to the circumstances and to the nature of the acts themselves by 
extreme example of an accepted damage assessment for which no certain metric exists is the pain and suffering award. ${ }^{200}$

Pain and suffering recovery has long been the subject of many exacting criticisms. A primary criticism has been that the difficulties of monetizing intangible loss lead to awards that vary significantly from one case to another and are not consonant with the compensatory principle of tort damages. ${ }^{201}$ Although these arguments seem fairly compelling, courts have been consistent in their position that the arguments do not warrant abolition of the pain and suffering award because it does continue to serve several useful purposes. ${ }^{202}$ Courts, however, do require that the award be fair and reasonable, often without offering a real guide for making that determination. ${ }^{203}$ As a consequence, a number of academics have put forth

which the damage is done. To insist upon less would be to relax old and intelligible principles. To insist upon more would be the vainest pedantry.

Ratcliffe v. Evans, 2 Q.B. 524 (C.A. 1892). Courts also have been known to invoke the maxim that a wrongdoer cannot complain about computational uncertainty resulting from his wrongful act. See CHARLES T. MCCORMICK, LAW OF DAMAGEs 102-03 (West 1935).

200. See Beagle v. Vasold, 417 P.2d 673, 681 (Cal. 1966) ("Every case which has considered the issue [of pain and suffering] ... has emphasized the difficulty faced by a jury in attempting to measure in monetary terms compensation for injuries as subjective as pain ....").

201. See generally Jaffe, supra note 176, at 219; Joseph H. King, Jr., Pain and Suffering, Noneconomic Damages, and the Goals of Tort Law, 57 SMU L. REv. 163 (2004); Robert L. Rabin, Pain and Suffering and Beyond: Some Thoughts on Recovery for Intangible Loss, 55 DePAUl L. REV. 359 (2006).

202. Pain and suffering damages can be justified as serving at least four distinct purposes: appeasing both the victim's and society's sense of outrage over the defendant's behavior; providing a sum out of which to compensate the victim for the expenses of litigation, including the fees paid to her attorney; deterring both the defendant and others from engaging in similar conduct in the future, and to provide the victim with the funds needed to pursue an alternative lifestyle that takes into account her injuries. See DoBBS, supra note 79 , at 550 .

203. See, e.g., Seffert v. L.A. Transit Lines, 364 P.2d 337, 342 (Cal. 1961) (stating that an award would be excessive if it "shocks the conscience and suggests passion, prejudice or corruption on the part of the jury"); Tucker v. Lower, 434 P.2d 320, 327 (Kan. 1967) ("[T]he only standard for evaluation is such amount as twelve reasonable persons estimate to be fair compensation when that amount appears to be in harmony with the evidence and arrived at without passion or prejudice."); Cuddy v. L \& M Equip. Co., 225 N.E.2d 904, 909 (Mass. 1967) (rejecting the argument that plaintiff's reference to possible per diem sums upon which the jury could calculate damages for pain and suffering were prejudicial). To help guide the discretion of the jury, Califomia has adopted a model jury instruction that authorizes the recovery of "[r]easonable compensation for any pain, discomfort, fears, anxiety and other mental and emotional distress suffered," and then instructs the jury that "[i]n making an award for pain and suffering you should exercise your authority with calm and reasonable judgment and the damages you fix must be just and reasonable in light of the 
theoretical proposals to make pain and suffering awards more predictable. $^{204}$

Two basic strategies for reform seem to dominate the literature. One is the idea that pain and suffering awards should be limited to a fixed percentage of the medical and related expenses. ${ }^{205}$ The other strategy involves constructing some sort of schedule of pain and suffering awards based on the kind of injury and age of the victim. The amounts could be determined by prior awards of a similar nature ${ }^{206}$ or by a consortium of experts. ${ }^{207}$ Of course there are problems with both strategies. They may not always work as well as the reformers said they would- hardly any reform ever does. ${ }^{208}$ But, I have already noted how arbitrary and capricious the tort system often is in imposing damage awards for pain and suffering; such caprice tends to undermine whatever deterrent effects the present system may otherwise have. If sanctions are to be effective as a deterrent they must be certain. The foregoing proposals do, at least, meet this criterion.

Are there analogies in the area of pain and suffering to determining damages for lost leisure time? We should start with the following three

evidence." Cal. Jury Instr.-Civ. 14.13 (2011).

204. There has also been legislative action aimed at making awards more predictable. Almost 30 states have sought to cap the amount recoverable, typically in medical malpractice suits. Some of these legislative efforts have, however, been overturned on state constitutional grounds. See Kevin Sack, Illinois Court Overturns Malpractice Statute, N.Y. TimES, Feb. 5, 2010, at A13 ("According to the American Medical Association, courts in 16 states have upheld the laws, while those in 11 states have overturned them.").

205. See, e.g., Marcus Plant, Damages for Pain and Suffering, 19 OHо ST. L.J. 200 (1958) (proposing that the award should be limited to 50 percent of medical and related expenses). Interestingly, Judge Posner has argued in favor of a ratio approach, when writing for the Seventh Circuit Court of Appeals in a wrongful death case involving a claim for loss of consortium damages. See Arpin v. United States, 521 F.3d 769, 777 (7th Cir. 2008) ("The first step in taking a ratio approach to calculating damages for loss of consortium would be to examine the ratio [of economic to noneconomic damages] in wrongful-death cases in which the award of damages was upheld on appeal.").

206. See, e.g., James F. Blumstein, Randall R. Bovbjerg \& Frank A. Sloan, Beyond Tort Reform: Developing Better Tools for Assessing Damages for Personal Injury, 8 YALE J. ON REG. 171, 178-79 (1991) ("[T] he middle range of prior awards of a similar nature should be given 'presumptive' validity.").

207. See, e.g., 2 The AMERICAN LAW InStITUTE, RePORTER'S StUdy: ENTERPRISE RESPONSIBILITY FOR PERSONAL INJURY 226 n.30 (1991) (the amounts would be determined "by a consortium of experienced judges, lawyers, insurers, doctors, and others, whose conclusions would then be adopted by the state legislature or the state supreme court").

208. The greatest problem with a ratio approach is that a plaintiff with small economic, but large noneconomic, losses would recover little. Likewise, a scheduling approach suffers from the questionable belief that all injuries can be fairly categorized. For a valuable critique of these strategies, see Mark Geistfeld, Placing a Price on Pain and Suffering: A Method for Helping Juries Determine Tort Damages for Nonmonetary Damages, 83 CALIF. L. REV. 773 (1995). 
benchmarks for assigning a dollar value to leisure time. First, whatever method is selected for use it should not discriminate against plaintiffs with little or no income. ${ }^{209}$ Second, we should embrace the assumption that everyone values their leisure time equally. That is, we should consider an approach that is not claimant-specific. ${ }^{210}$ Third, there is a great deal to be said in favor of providing a formula that can be easily administered to yield awards that are consistent across cases and in amounts that seem appropriate to many.

Over the past several decades, there has been a growing recognition among forensic economists that the enjoyment of life is a component of the value of life and should be recognized as a separate element of damages in wrongful death and personal injury cases. ${ }^{211}$ While subtle nuances and thematic variations exist, there appear to be two basic ways of making this hedonic calculation. The first method of valuing the enjoyment of life might best be termed the "willingness-to-pay" ("WTP") approach. ${ }^{212}$ The first step is to determine what an average person people would pay to have his or her risk of fatal injury reduced by a very small amount. Economists Michael Brookshire and Stan Smith have identified a number of sources that can be consulted for this information. They include:

1) Studies based on data regarding what private citizens spend on items they use to increase their own safety, such as airbags, smoke detectors, larger tires and so forth.

2) How much more customers pay to fly on airlines with better safety reputations and similar consumer expenditures based on safety differentials in service delivery.

209. Indeed, for this reason, one might legitimately object to a ratio approach to pain and suffering awards that is based on components of pecuniary injury that includes lost earnings capacity.

210. I am of the opinion, therefore, that the court in Daniel v. Virgin Atlantic Airways Ltd., 59 F. Supp. 2d 986 (N.D. Cal. 1998) was mistaken in its view that "[t]he amount of compensation could vary dramatically depending on what the [plaintiff] was prevented from doing ...." Id. at 994 n.6. Whether the plaintiff was deterred from playing golf or attending the wedding of a close friend or relative should not matter. The whole idea that a judge or jury can rank the relative value of various activities in a meaningful way is simply preposterous. No one is an expert on another person's pleasures. The damages in all cases should be uniform and based on the intrinsic value of leisure time.

211. For an overview of existing case law on the issue of hedonic damages, see supra notes $81-95$ and accompanying text.

212. This method has its genesis in a 1968 article by Thomas Schelling. See generally Thomas Schelling, The Life You Save May be Your Own, reprinted in ThOMAS SCHELlng, CHOICE AND CONSEQUENCE 113 (Harvard Univ. Press 1984). 
3) How much more workers must be paid to accept jobs with greater life risk, such as coal mining or high beam welding. ${ }^{213}$

By determining what an individual would pay to reduce the risk of death or injury or the wage premium demanded to accept a position with an increased risk of death or injury, the intrinsic value of life can be inferred. For example, if individuals willingly spend $\$ 1,000$ to reduce the risk of death by $0.01 \%$, it can be inferred that the whole value of an individual's life is $\$ 10$ million $(\$ 1,000 / 0.0001) .^{214}$

The foregoing whole life value does not, however, measure the value of specific aspects of life. The next and final step in putting a specific dollar figure on the enjoyment of life component of an individual's life is to subtract from the whole life value the present value of household production and the income stream that would be derived from time spent in market activities for the remainder of the individual's life expectancy.

This approach to arriving at hedonic value or enjoyment is not without challenge. For example, wage-risk premium studies assume labor mobility and that individuals have perfect information about job safety. At least one commentator has questioned the accuracy of these twin assumptions. ${ }^{215}$ Another common criticism is that the estimated value of an anonymous or statistical person is not the same as the value that an individual places on her own life. ${ }^{216}$ Regardless of the merits of these and other criticisms of the WTP approach as a basis for measuring the hedonic value of life, it is not a methodology that is suitable for lost leisure time valuations in the vast run of cases. One basic point is decisive: it lacks administrative convenience in application. Whether WTP-based values are derived from wage-risk studies, consumption studies, or surveys posing hypothetical questions about risk, the approach requires time-consuming and expensive expert testimony by forensic economists. These costs may be justified in the highstakes world of wrongful death and serious personal injury, but are hardly justifiable in the run-of-the-mill leisure time case involving relatively few hours.

213. Michael L. Brookshire \& Stan v. Smith, Economic/Hedonic Damages: The Practice Book for Plaintiff and Defense AtTorneys 167 (Anderson Pub'n Co. 1990).

214. See, e.g., Glenn Blomquist, Value of Life Saving: Implications of Consumer Activity, 87 J. POL. ECON. 540 (1979) (assessing the value of a person's life to be $\$ 370,000$ based on seatbelt use); Craig A. Olson, An Analysis of Wage Differentials Received by Workers on Dangerous Jobs, 16 J. HUM. RES. 167 (1981) (assessing the value of a person's life to be $\$ 3.2$ million based on the premium paid to workers in dangerous jobs).

215. See, e.g., William T. Dickens, Assuming the Can Opener: Hedonic Wage Estimates and the Value of Life, $3 \mathrm{~J}$. FoRENSIC ECON. 51 (1990).

216. See, e.g., Thomas Havrilesky, The Misapplication of the Hedonic Damages Concept to Wrongful Death and Personal Injury Litigation, 6 J. FoRENSIC ECON. 93 (1993). 
A second approach to estimating the value of life and its component, the enjoyment of life, rejects the indirect calculation that underlies the WTP methodology, and substitutes, instead, a direct measurement of three components of life: work, services, and enjoyment. The important insight provided by this approach is that, because each person allocates his or her time so as to maximize total utility, on the margin, the value of each component has the same price. Thus, it is accurate to say that that price is at least the market-equivalent wage rate applicable to the individual's actual or potential employment opportunities. Gary Becker, the 1992 Nobel Prize winner in economics, observes that "[t]he marginal utility from all uses of time are equal in equilibrium because they have the same price (w), and the marginal rate of substitution between time and each good equals the "real" wage rate, where the price deflator is the price of the good."217 Thus, if an individual has a current wage rate of $\$ 15$ per hour, the value of her lost leisure time would also be estimated at $\$ 15$ per hour. ${ }^{218}$

By providing an approach that has the advantage of making the value of leisure time relatively easy to establish, the cumulative method of valuation may appear, at first blush, to bring us to the end of our pragmatic search for a suitable method to set damages in lost time cases. Moreover, in addition to its efficacy, it has the added advantage of keeping courts out of the business of ranking the worth of various activities. But this approach suffers from two deficits.

Let us understand first that using an individual's actual wage-rate as a measuring rod to value lost leisure opportunities raises substantial equality concerns. To my mind, such an approach is inconsistent with the dignity of universal human worth by positing that leisure time is worth more to neurosurgeons than it is to law professors. Why would this be? After all, it might well be that those with lower paying jobs under difficult conditions may value their leisure time more than those who toil in high paying positions that bring with them high degrees of respect and self-satisfaction. What is needed is a damages rule that is indifferent to the earning characteristics of different people, but simply seeks to measure lost time in a manner that is not intractably discriminatory.

217. Gary S. Becker, A TReatise on the Family 22 (Harvard Univ. Press 1991).

218. For a good discussion of the application of this approach to an injured housewife, see Richard A. Posner, Economic ANalysis of LaW 80 (Little, Brown \& Co. 1972). It is suggested that the appropriate wage-rate should be assessed net of taxes since the return on nonmarket time is not taxable. Id. Thus, that would be the rate that an individual would consider relevant when trading between work time and leisure time so as to maximize his total utility. Because the effect of taxes on the total recovery in the type of case envisioned by this Article would be de minimis, I suggest that they should be ignored. Their consideration would only add an unnecessary complicating feature to the calculation. For these two reasons, I would also ignore the typical work-related expenses of transportation, clothing, etc. 
Even if I am reluctant to embrace an approach that implicitly rejects the assumption that everyone enjoys life equally, the notion that earnings in the market (i.e., "opportunity cost of leisure time") provides the basis for an acceptable standard of measurement should hardly be dismissed in toto. If it is just the claimant-specific determination that is troublesome, then why not simply use the median or mean wage-rate paid by employers in all industry sectors in metropolitan and nonmetropolitan areas as the relevant real wage? $?^{219}$

There is still one more step to consider. A disadvantage of lost leisure valuation based on the composite median or mean wage is that in some cases-indeed perhaps in most cases-we would have to make an upward adjustment to the hourly wage-rate of specific individuals to truly reflect the realities of the marketplace. In an unpublished paper, Melville Wolfson advances the truly novel notion that leisure time is worth more than working time ${ }^{220} \mathrm{He}$ argues that the hourly earnings rate undervalues leisure time because it neglects to take into account the real possibility of an overtime premium, which can be time-and-a-half, double-time and sometimes even triple-time, depending upon the industry. Thus, in his view, some multiple $(1.5,2.0$ or 3.0$)$ of the hourly earnings rate should be used. ${ }^{221}$

Admittedly, there is room for disagreement about what the multiple for valuing leisure time ought to be. If, however, tort and contract law are to be understood from a meliorative perspective, it is clear to me that some multiple should, in fact, be used. Probably the two most common social policies promoted by both tort and contract law are the compensation for losses and the creation of incentives for optimal levels of behavior. When tort and contract law are assessed in connection with their meliorative functions, one may question the wisdom of adopting a measure of damages that increases the likelihood of undercompensation. Other things being

219. A snapshot of these wages can be obtained from the U.S. Department of Labor. See, e.g., NATIONAL OCCUPATIONAL EMPLOYMENT AND WAGE ESTIMATES (May 2010), http://www.bls.gov/oes/current/oes_nat.htm (documenting a median hourly rate of $\$ 16.57$ and a mean hourly rate of $\$ 21.74$ ). Because the primary purpose of this Article is to provide a conceptual legal and economic framework for assessing the loss of leisure time, I leave the choice between the two wage-rates to the court or state legislature. States may choose to pass statutes as a means of resolving this problem. Statutes prescribing a rate of interest on claims and judgments provide a workable model. See, e.g., 28 U.S.C.A. $§ 2516$ (2011); VA. CODE ANN. $\S 6.2-302$ (2011). If a specific dollar amount is selected, legislatures should pay heed to increases in the wage-rate and increase the statutory amount from timeto-time, as necessary.

220. Professor Wolfson's death prevented him from completing the paper. For an abstract and Editor's Note explaining his thesis, see Melville Z. Wolfson, Is Leisure Time Worth More Than Working Time, 14 J. FORENSIC ECON. 35 (2001).

221. A second reason suggested for using a multiple is that the true yield to a worker for a marginal hour at work should include the utility or pleasure gained from the act of working. See id. at 36. 
equal, the wrongdoer should bear the slight risk that the specific multiple chosen might overvalue leisure time. Without this kind of approach, it is hard to see that the policies of contract and tort law can be implemented on a large scale. I need not now assess the relative strength of these multipliers. Nor need I conclude whether the selection should be by the court or legislature. None of this is necessary to understand the more central point: the lost leisure valuation should posit an equal quality of life for all individuals.

\section{CONCLUSION}

In this Article, I have attempted to demonstrate some of the deep flaws in the reluctance of courts to award damages for lost leisure time, particularly in breach of contract cases. This reluctance, coupled with the fact that it adds to the pervasive undercompensation of contract plaintiffs is not without social significance. ${ }^{222}$ I have sought to demonstrate that there are strong policy grounds for setting damages at an amount that equals the value of what the plaintiff has lost. The two most basic of these are to compensate the aggrieved party and to deter conduct that brings about more harm than good. I have attempted to show that the present structure of damages, by not giving much attention to claims for lost personal time, has created the possibility of a divergence between loss and compensable damages, and is thus insensitive to these policy grounds. In this Article, I offer a conceptual framework based on this observation. Finally, I have argued that existing techniques for measuring leisure time are either administratively cumbersome or are anti-egalitarian. I propose a technique that is narrowly tailored to respond to these two deficiencies.

The lack of judicial and academic attention to lost leisure time situations is in some sense astonishing, considering the plethora and diversity of contexts in which this type of loss is likely to occur. ${ }^{223}$ It suggests that the traditional common law position against recovery of

222. Undercompensation of contract plaintiffs results, in no small part, from the continued adherence of courts to the American rule on attorneys' fees. Unless the contract or a statute provides otherwise, each party is ultimately responsible to compensate her own attorney. See generally Symposium, Attorney Fee Shifting, 47 L. \& CONTEMP. ProBS. 1 (1984). For tort plaintiffs, on the other hand, punitive damages and pain and suffering awards can help ease the burden of litigation expenses.

223. See supra notes 11-16 and accompanying text. Another example of an everyday scenario that implicates such a nonpecuniary loss involves a frustrated consumer seeking to rectify a problem caused by a commercial provider of goods or services. For example, in a telephone interview, Richmond, Virginia attomey Anne Stratton explained that a lawsuit she had filed against Verizon for time spent seeking to correct a variety of billing errors was dismissed because the court refused to recognize that lost time was a compensable injury. Telephone Interview with Anne Stratton, Attorney (Jan. 8, 2012). 
nonpecuniary damages generally has a powerful hold on our legal intuition. A re-evaluation of this slighted area would be good public policy and, it's about time. 